\title{
Corruption and Political Stability: Does the Youth Bulge Matter?
}

\author{
Mohammad Reza Farzanegan \\ Stefan Witthuhn
}
CESIFO WORKING PAPER NO. 5890
CATEgory 2: Public CHOICE
MAY 2016
An electronic version of the paper may be downloaded
- from the SSRN website:
- from the RePEc website:
- from the CESifo website:
www.SSRN.com
www.RePEc.org
www.CESifo-group.org/wp




\title{
Corruption and Political Stability: Does the Youth Bulge Matter?
}

\begin{abstract}
This study shows that the relative size of the youth bulge matters for how corruption affects the internal stability of a political system. We argue that corruption cannot buy political stability (e.g., the greasing hypothesis) in countries with a relatively large youth population. Using panel data covering the 2002-2012 period for more than 100 countries, we find a negative interaction effect between the relative size of the youth population and corruption on internal political stability. Corruption is a destabilizing factor for political systems when the share of the youth population in the adult population exceeds a threshold level of approximately $19 \%$. The negative interaction term is robust, controlling for country and year fixed effects, a set of control variables that may affect internal political stability, an alternative operationalization of youth bulge, and a dynamic panel estimation method.
\end{abstract}

JEL-Codes: D730, D740, E020, H560, J110.

Keywords: demographic transition, youth bulge, political stability, corruption.

Mohammad Reza Farzanegan* CNMS, Middle East Economics Dep.

Philipps-University of Marburg

Deutschhausstrasse 12

Germany - 35032 Marburg

farzanegan@uni-marburg.de
Stefan Witthuhn

Berghof Foundation

Tübingen / Germany

*corresponding author

This version: 05.05.2016

We thank the useful comments of Toke Aidt, Pooya Alaedini, Sajjad Dizaji, Dalia Fadly, Jerg Gutmann, Alireza Naghavi, Florian Neumeier and, Jan-Egbert Sturm and partcipants in 71st Annual Congress of the International Institute of Public Finance (2015, Dublin), Silvaplana 24th Workshop on Political Economy (2015, Pontresina), European Public Choice Society (2015, Groningen) and CNMS-Institutskolloquium (2015, Marburg). 


\section{1- Introduction}

We aim to better illuminate an issue that is still controversial in the economic development literature: the influence of the perception of corruption on political stability ${ }^{1}$ and the moderating role of demography. Does the effect of corruption on political stability depend on the level of the youth bulge size? This is a novel question, and the answer will guide policy makers and international organizations in better allocating the anti-corruption budget, taking into account the demographic structure of societies and the risk of political instability.

There are arguments in the literature for both the positive and negative effects of corruption on political stability. Fjelde (2009) shows that corruption can moderate the negative stability effects of oil rents. She concludes that a "selective accommodation of private interests" through political corruption may reduce the risk of armed conflict in (oil) resource-rich countries. Others such as Neudorfer and Theuerkauf (2014) have different opinions. They show a positive (i.e., increasing) effect of corruption on the risk of ethnic civil war, which is a main factor in government instability. They suggest that corruption distorts political decision making and increases the political and economic inequalities between different ethnic groups and, ultimately, the risk of large-scale conflict and instability.

Another stream in the literature focuses on the economic growth effects of corruption with indirect implications for political instability. Some provide support for the "greasing" hypothesis, in which corruption helps moderate the negative effects of dysfunctional regulations and low-quality institutions (Leff, 1964; Huntington, 1968; Dreher and Gassebner, 2013; Méon and Weill, 2010). According to the World Bank (private) firm-level survey database, approximately $20 \%$ of firms around the world are expected to give gifts to public

\footnotetext{
${ }^{1}$ In this study, we follow Bjorvatn and Farzanegan (2015) and use "internal conflict" and "political instability" interchangeably. We use the internal conflict index of the International Country Risk Guide (ICRG, 2015) published by the Political Risk Services (PRS) group. Their internal conflict index varies from 0 (the least stable system) to 12 (the most stable system). That is, higher scores are given to countries in which there is no armed or civil opposition to the government and the government does not indulge in arbitrary violence, directly or indirectly, against its own people, whereas the lowest scores are given to countries that are experiencing an ongoing civil war. Thus, this index is related to the experience of actual violence or political instability. According to the ICRG (2015), countries with a lower probability of civil war/coup threat, terrorism/political violence, and civil disorder also enjoy a higher degree of political stability.
} 
officials "to get things done". There is variation across regions: the lowest percentage of such experience is reported for the Organisation for Economic Co-operation and Development (OECD) firms (8\%) and the highest for Sub-Saharan African firms $(27 \%){ }^{2}$ This stream of literature suggests that corruption assists firms in addressing widespread inefficiency in public governance and the provision of public goods (see Vial and Hanoteau, 2010 and Kato and Sato, 2015).

In contrast to this stream in the literature, there are studies that suggest that corruption is (more) an obstacle to development (Aidt, 2009). Corruption distorts public funds and directs them towards areas where bribes can be more easily collected, such as capitalintensive infrastructure projects, rather than investing in the employment-intensive health care and education sectors (Mauro, 1995; Gupta et al., 2001; Blackburn and Sarmah, 2008). Peoples' talents concentrate on rent seeking in corrupt societies rather than on long-term benefits (Mo, 2001). Corruption affects the poor by reducing social services. By contrast, it can be argued that it benefits the well-connected individuals of society, who are likely to be found in the high-income class (Gupta et al., 2002). Corruption has also serious implications for the quality of public goods. One example is the negative effects of corruption on environmental quality, increasing deforestation and air pollution and reducing access to public goods such as drinking water and sanitation (e.g., Fredriksson and Svensson, 2003; Anbarci et al., 2009; and Biswas et al., 2012). Several studies have shown the role of environmental degradation in political instabilities across the world (Hendrix and Salehyan, 2012; Hsiang et al., 2011).

A further study links corruption to political stability by investigating the transmission channels of corruption for economic growth (Mo, 2001). The results show that a one-unit increase in corruption in the 1999 Transparency International-CPI corruption index reduces economic growth by 0.545 percentage points. One of the major transmission channels of the

\footnotetext{
${ }^{2}$ See http://www.enterprisesurveys.org/data/exploretopics/corruption.
} 
growth effects of corruption is political (in)stability. Political instability following increasing corruption accounts for $53 \%$ of the total negative effect of corruption on growth. Other channels through which corruption reduces growth are the negative effects on human capital and private investment. In a recent study, Dorsch et al. (2015) show that corruption (in the form of rent seeking) triggers instability effects of macro-economic shocks in autocracies.

Our contribution is to introduce the youth bulge as a catalyst in the stability-corruption nexus. The core of our research question is to examine whether the effect of corruption on political stability is conditional on the relative size of the youth bulge. This question has been less investigated in the literature. The term "youth bulge" has been highlighted mostly by political scholars such as Fuller (1995), Goldstone (1991) and Heinsohn (2006, 2007). A high population growth over a limited period of time consequently leads to a relative large youth cohort, the so-called 'window of opportunity'. Although some countries can take advantage of this opportunity, a large, young, working-age population can also be a challenge if the state's capability to address the situation is limited (Nordås and Davenport, 2013). If a large youth cohort coincides with a stagnant economy and vast unemployment, then the chances for political instability also rise because of the low opportunity costs of engaging in political violence incurred by young men (Barakat and Urdal, 2009; Collier and Hoeffler, 2004; Weber, 2013; Bricker and Foley, 2013; and Yousef, 2003).

The demographic transition in countries with a high perception of corruption may hardly lead to a demographic bonus. Instead, we may expect to experience a demographic curse, especially with respect to political stability. An example is the uprisings in the Arab world since 2011, in which the youth population has been a driving force. Pervasive corruption had been a major concern for the population of this region well in advance of the so-called Arab Spring. According to Diwan (2013), "the perceived corruption of the political and business elites was a key driving force of popular discontent". He quotes the Pew survey in 2010 , in which the perception of corruption was ranked as the main concern of $46 \%$ of 
Egyptians, ahead of other concerns such as the lack of democracy and poor economic conditions. The youth participation in the Arab Spring (since 2011), the Iranian Green Movement (the post-2009 presidential election) and the Color revolutions (e.g., in Yugoslavia's Bulldozer Revolution (2000), in Georgia's Rose Revolution (2003), and in Ukraine's Orange Revolution (2004)) is well documented. ${ }^{3}$

Other studies have investigated the combined effects of other dimensions of institutions such as the regime type and the youth bulge on political stability. Goldstone (2002) and Urdal (2006) show that the risk of political instability is higher when autocratic states face a youth bulge. Political participation is limited in autocratic states, and large youth cohorts imply that more young people compete for few opportunities, which leads to frustration and a willingness to engage in political violence. The combined effect of education and the youth bulge on stability has also been investigated. The results of an interaction term for the youth bulge and education suggest that conflict (and its resulting instability) is more likely to occur when the level of education is low (Barakat and Urdal, 2009).

We use panel data country and year fixed effects and dynamic panel data regressions for more than 100 countries from 2002 to $2012^{4}$. Controlling for the main drivers of political stability, our results show that the final stability effects of corruption depend on the youth bulge. This result is robust to different measurements of the youth bulge and the inclusion of other relevant interaction terms. Increasing corruption in countries with a higher youth population leads to political instability. Anti-corruption reforms, which are costly to implement, will be more effective in securing stability in countries with a high relative size of the youth population, and therefore, the funds for such reforms should be allocated more to such countries.

\footnotetext{
${ }^{3}$ For more details on the important role of youth as a catalyst for mass street protests in 1990 and then in 2004, see Diuk (2013). The latter is known as the Orange Revolution. On the increasing importance of youth within the Iranian social and political environment, see Nesvaderani and Memarian (2010).

${ }^{4}$ The availability of data on corruption from the World Governance Indicators (WGI) of the World Bank (Kaufmann et al., 2010) is the reason for the use of this time period.
} 
The remainder of this paper is structured as follows. Section 2 presents the data and our empirical strategy. The results and robustness checks are presented and discussed in Section 3. Section 4 concludes the paper.

\section{2- Empirical research design}

Data, specification, and empirical strategy

Our main hypothesis is that the demographic transition and, in particular, the relative size of the youth bulge matter for whether the extension of corruption is a politically stabilizing or destabilizing force. Specifically, perceptions of corruption are more likely to have a destabilizing effect when the youth bulge is relatively large. Allocating limited economic and financial resources to anti-corruption reforms can be guided by understanding the demographic structure of target countries to the extent that their internal stability matters to policy makers. In this context, we also control for other competing hypotheses (e.g., the relevance of democracy, economic performance and education). This strategy helps reduce the risk of ignoring other important moderating channels noted in the literature.

We test our hypothesis using panel regressions for more than 100 countries from the 2002-2012 period. To estimate whether the relationship between corruption and political stability varies systematically with the level of the youth bulge, we use the following specification:

$\operatorname{stab}_{-}$icrg $_{i t}=\mathrm{cons}+\beta_{1} \cdot \operatorname{cor}_{i t-1}+\beta_{2} \cdot$ youth $_{i t-1}+\beta_{3} \cdot\left(\operatorname{cor}_{i t-1} \times\right.$ youth $\left._{i t-1}\right)+\beta_{4} \cdot Z_{i t-1}+u_{i}+$ $\theta_{t}+\varepsilon_{i t},(1)$

with country $i$ and time $t$,

where stab_icrg is the political stability index, cor is a measure of the perception of corruption, youth is the relative size of the youth cohort, cor $\times y$ outh is the interaction of corruption and the youth bulge, and $Z$ is the control variables. All explanatory variables are lagged one year to reduce possible reverse feedback (for a similar approach, see Bjorvatn et 
al., 2012). According to our expectations, the sign of the interaction term coefficient should be negative $\left(\beta_{3}<0\right)$; the higher the relative size of the youth bulge is, the lower (higher) the stability (instability) effect of corruption should be.

The marginal stability effect of the perception of corruption can be calculated by examining the following partial derivative on the basis of Equation (1):

$\frac{\partial\left(\text { stab_icrg }_{i t}\right)}{\partial\left(\text { cor }_{i t-1}\right)}=\beta_{1}+\beta_{3} \cdot\left(\right.$ youth $\left._{i t-1}\right)$

Dependent variable: Political stability (stab_icrg)

Our dependent variable is a measure of political stability. In this study, our main proxy for measuring (in)stability is the internal conflict index of the International Country Risk Guide (ICRG, 2015) published by the Political Risk Services (PRS) group. This index varies from 0 (the least stable system) to 12 (the most stable system). Higher scores mean a lower risk of internal conflict and terrorism, in other words, higher internal political stability. Higher scores are given to countries in which "there is no armed or civil opposition to the government and the government does not indulge in arbitrary violence, directly or indirectly, against its own people". The lowest scores are given to countries that are "experiencing an ongoing civil war". Thus, this index is related to the experience of violence or political instability.

The index is the sum of the following three sub-components directly related to internal stability: civil war/coup threat; terrorism/political violence; and civil disorder. ${ }^{5}$ Civil disorder refers to mass protests, such as anti-government demonstrations, and strikes and the potential risk they pose to governance or investment. Terrorism is defined in terms of forces opposed to the government that perpetrate violent acts against civilian or state targets to achieve a

\footnotetext{
${ }^{5}$ For more details on the methodology of this index, see http://www.prsgroup.com/wpcontent/uploads/2012/11/icrgmethodology.pdf.
} 
political goal. The fundamental difference between a terrorist campaign and a civil war is that the former does not hold and manage territory within a nation state. ${ }^{6}$

The ICRG internal conflict index is also used in a large number of studies on political stability (e.g., Gupta et al., 2004; Jinjarak, 2009; Bjorvatn and Farzanegan, 2013, 2015, Long, 2008; Neumayer, 2004; Lessmann, 2016). We have also examined our hypothesis by using an objective measure of conflict, namely, the maxintyearv413 variable in the UCDP Monadic Conflict Onset and Incidence Dataset (Themnér and Wallensteen, 2014 and Gleditsch et al., 2002). There is a negative and significant correlation between the risk of internal conflicts from ICRG and maxintyearv413 (-55\%). Regressing the intensity of conflict on the lag of internal conflict from the ICRG (our stability index), controlling for country and time fixed effects gives the coefficient of -0.07 , with robust $t$-statistics of -2.82 . These results provide more evidence regarding the relevance of the subjective indicator of conflict in predicting the real onset of minor or major internal conflict. The results of a conditional fixed effects (country and year) logistic regression, which uses a major conflict dummy (1 for countries/years with more than 1000 deaths and 0 otherwise) as the dependent variable and corruption, the youth bulge, their interaction and the youth unemployment rate as the independent variables, are in line with our main finding. The final effect of corruption on major conflicts depends on the size of the youth bulge. The interaction term has a positive and significant (at the 95\% confidence interval) effect. Finally, de Groeve et al. (2014) have highlighted several critical issues with regard to using counted conflicts, supporting our application of the internal conflict risk scores of the ICRG. Lessmann (2016) shows that the ICRG conflict scores and binary conflict variables are correlated and both point in the same direction.

6 A detailed definition of the variables used to calculate the ICRG index is available at http://epub.prsgroup.com/list-of-all-variable-definitions. 


\section{Independent variables}

\section{Corruption (cor)}

We use the control of corruption index of the World Governance Indicators (WGI) of the World Bank (Kaufmann et al., 2010). ${ }^{7}$ It captures "(the views and perceptions of firms and households) of the extent to which public power is exercised for private gain, including both petty and grand forms of corruption, as well as 'capture' of the state by elites and private interests". The index varies from approximately -2.5 (the most corrupt) to 2.5 (the least corrupt). We have reversed the scale to interpret higher values as more corruption. The index is based on an aggregation of information from several other sources (household, businesses and NGOs surveys) that reflect both the perception and the experience of corruption. ${ }^{8}$ This composite corruption index is the first principal component of a number of other commonly used corruption indices. It is highly correlated with Transparency Internal (TI) corruption scores. One major advantage of the WGI corruption index over TI index is clear documentation of its aggregation method and its broader coverage of countries. The control of corruption index of the World Governance Indicator has been extensively used in related literature (e.g., Fisman and Miguel, 2007; Fisman and Wei, 2009).

One source of concern is the extent of the correlation between the perception of corruption and its actual experience. If these two show a weak correlation or no correlation, then we may want to reconsider our application of perception-based indicators in the analysis. Fisman and Miguel (2007) and Fisman and Wei (2009) provide some interesting evidence for the objective validation of subjective perceptions of corruption. Fisman and Miguel (2007) investigate the reasons behind UN diplomats' propensity to abuse their diplomatic immunity to violate New York City parking rules. They find robust evidence that this propensity is

\footnotetext{
${ }^{7}$ We have not used the corruption index from the ICRG because we use the stability index from the ICRG as a dependent variable. It may be the case that a perception of corruption of a country expert may be influenced by his/her views on political stability. Using different sources of information on these variables may reduce potential concerns.

For more details on the components and sources of the WGI corruption index, see http://info.worldbank.org/governance/wgi/cc.pdf.
} 
strongly correlated with the corruption perception level (measured by the WGI Control of Corruption index) of the diplomats' country of origin. Fisman and Wei (2009) show that there is a positive and significant correlation between the exporting country corruption perception (based on the WGI index) and the size of mis-invoicing in trade documents. By examining the International Crime Victim Survey (ICVS), Lambsdorff (2007, p. 24) provides further examples concerning the validity of perceptions of corruption. The developers of the World Governance Indicators have also reflected on the relevance of perceptions-based indicators such as corruption: "Perceptions-based data are a valuable tool for capturing the realities of governance outcomes 'on the ground', which may be very different from the formal rules 'on the books' that can be captured with objective data. In some areas, notably corruption, it is nearly impossible to measure governance in any other way than by relying on the experiences and views of informed respondents. The distinction between 'subjective' and 'objective' measures of governance and the investment climate is mostly a superficial one, as nearly all such measures rely on judgment and/or legal opinions and experiences of respondents in varying degrees". 9

Another concern is that perceptions may also be vulnerable to the news about corruption cases across countries. If locals and country experts are only following the news about corrupt cases, depending on the frequency of such news in the media, then they may change their perception. Countries that monitor and censor the media may avoid a negative reputation for a corrupt government. However, the literature shows that there is a positive correlation between the control of the corruption perception index and the freedom of the press. In other words, the perception of corruption in less media-free countries is also higher (see Besley and Prat, 2006; Brunetti and Weder, 2003; and Sung, 2002).

\footnotetext{
${ }^{9}$ See http://info.worldbank.org/governance/wgi/index.aspx\#faq-16.
} 


\section{Youth bulge (youth)}

The relative size of the youth population is our moderating variable in the stabilitycorruption nexus. There are two frequently used proxies for measuring the size of the youth bulge in the literature. One group of studies uses the share of youth (typically defined as the number of individuals in the population 15 to 24 years of age) in the total population: Youth1524_totalpop. For example, Collier (2000), Fearon and Laitin (2003), Collier and Hoeffler (2004), Goldstone (2001), and Huntington (1996) apply this proxy to measure the relative importance of the youth bulge. The second group uses the share of the youth population (the same definition as above) in the total number of individuals in the adult population (15 years of age and higher: Youth1524_15plus).

Urdal (2004) argues that the first proxy (youth as a share of the total population) produces "serious flaws that could easily jeopardize the possibilities of revealing the effects of youth bulges" on conflict. From the youth revolts theoretical framework, this is the competition between younger and older cohorts, which can lead to conflict. From an empirical perspective, in countries with a higher population growth, the use of the youth population as a share of the total population tends to underestimate the importance of the youth cohort. The reason is the population under 15 years of age that inflates the total population. To avoid this problem, Urdal (2004, 2006, and 2012) recommends the second proxy. We use Urdal's suggested proxy in our main analysis to measure the relative size of the youth bulge, testing other measurements as a robustness check.

\section{Country and time fixed effects}

There are also country-specific factors that may shape the stability of a political system. Factors such as geographical location, cultural and historical heritage, norms and regional conventions related to political power, and religion may foster political instability or secure the stability of a system. Ethnolinguistic fractionalization is another country-specific factor that is relevant for the stability of political systems (Collier and Hoeffler, 1998). We 
control for such unobserved time-invariant factors by including country fixed effects $\left(\mu_{\mathrm{i}}\right)$. In addition, we control for the common time shocks that may affect the political stability of all countries in our sample simultaneously $\left(\delta_{\mathrm{t}}\right)$. Examples include events such as the financial and economic crisis in 2008-2009, the Iraq war in 2003 and the Arab Spring. If such countryspecific or time-specific factors are correlated with a youth bulge or corruption, then both pooled cross-section and random effects estimations may lead to biased and inconsistent results.

\section{Control variables}

In our empirical specification, $Z$ covers other control variables that have been shown to have an influence on political stability: natural resource rents are noted as an important factor in buying peace or war. On one hand, increasing rents can enhance the financial leverage of the state against political opposition. On the other hand, the availability of significant resource rents may increase the benefits of engaging in a movement of rebellion to capture political power (Bjorvatn and Farzanegan, 2015). We control for the total natural resource rents as a share of GDP.

We also control for the GDP per capita growth rate to take into account the opportunity costs of participation in civil disorder for the youth population (de Soysa, 2002). Brückner and Gradstein (2015) examine the effects of GDP per capita growth on political risk. They find a negative effect of income growth on countries' political risk. Another stream in the literature shows that economic shocks cause instability and regime transitions (see the two seminal papers by Brückner and Ciccone, 2011 and Burke and Leigh, 2010). Using the case of Sub-Saharan Africa, Aidt and Leon (2015) show that riots (which are more likely in places with many unemployed young people) play an important moderating role in this nexus. The population growth rate is another control variable. The deprivation hypothesis suggests that population growth and its subsequent environmental burden can impoverish individuals, 
reducing the opportunity cost of civil disorder. The state weakness hypothesis agrees with the deprivation thesis but also adds that impoverished individuals may not automatically engage in civil disorder, which depends on the effects of the population growth and the capacity of the state to maintain order. Kahl $(1998,2006)$ adds the third hypothesis, namely, state exploitation, using Kenya as a case study to show that "countries plagued by severe population and environmental pressures will experience state-sponsored violence". We also control for variables such as trade openness (imports plus exports \% of GDP) and foreign direct investment ( $\%$ of GDP). The effects of these variables on political stability are mixed. They can increase stability by increasing economic opportunities and employment and thus reducing the poverty of locals. They may also lead to more income inequality, especially in countries with a high level of corruption and rent seeking, destabilizing the political system. Barbieri and Schneider (1999) provide a review of the literature on the trade-conflict nexus. Education can matter as well. Higher education can increase the economic opportunities for young people, raising the economic costs of civil disorder. However, increasing the education coverage while the quality of economic and political institutions is weak may eventually lead to a larger informal economy and other socio-economic and political challenges (Buehn and Farzanegan, 2013). We use gross secondary school enrollment (\%), which is the total enrollment in secondary education, regardless of the age of the students, expressed as a percentage of the population at the official secondary education age. The youth unemployment rate $(\%)$ is another important driver of political instability (see Azeng and Yogo, 2013). In addition, corruption may affect political stability through the distribution of income in society. A highly unequal distribution of income and wealth is shown to be a significant driver of political instability and conflict (Sigelman and Simpson, 1977; Alesina and Perotti, 1996). We use net income inequality (post-tax and post-transfer) data from the Standardized World Income Inequality Database (Solt, 2009) ${ }^{10}$.

\footnotetext{
${ }^{10}$ The results are the same when we use the market Gini index (pre-tax, pre-transfer Gini).
} 
We also control for the quality of political institutions. The level of democracy may influence both political stability and corruption. It can also influence the stability effects of the youth population. The level of democracy itself can have ambiguous effects on stability. Opposition forces have better opportunities to challenge the ruling government in a more democratic environment, but the motive perspective suggests that the youth population has more incentives to use radical methods under repressive governments. Urdal (2006) argues that final stability effects of youth depend on the level of democracy. To measure democracy, we follow Dahl's (1971) discussion of democracy and use the Vanhanen index of democracy $^{11}$. The two main components of the Vanhanen index of democracy are political competition and political participation (Vanhanen, 2000). Unlike other measures of democracy, it is based on objective information. The correlation between this objective measure of democracy and the subjective measure of voice and accountability of the World Governance Indicators ${ }^{12}$ is significant and positive (81\%).

We also check for competing hypotheses by controlling the interactions of education, democracy, economic growth and youth unemployment with the youth bulge. Except for political stability, youth bulge, corruption and democracy, all variables are from the World Bank (2015). The source of information for the demographic variables is the Population Estimates and Projections database of the World Bank. ${ }^{13}$

We control for arbitrary heteroskedasticity and serial correlation by using clusterrobust standard errors at the country level (Wooldridge, 2002). Table A1 in the Appendix presents the summary statistics for the main variables of the analysis. The descriptions of the variables in main analysis are presented in Table A2 in the Appendix.

\footnotetext{
${ }^{11}$ See http://www.fsd.uta.fi/en/data/catalogue/FSD1289/meF1289e.html.

12 This index captures the perceptions of the extent to which a country's citizens are able to participate in selecting their government, in addition to freedom of expression, freedom of association, and a free media. In the regressions, we control the Vanhanen index to avoid multicollinearity problems by including both the voice and corruption indices from the WGI on the right-hand side of the model.

${ }^{13}$ See http://data.worldbank.org/data-catalog/population-projection-tables.
} 


\section{3- Main results}

Table 1 presents the country and years fixed effects regression results, which show the within-country changes in political stability in response to within-country changes in the right-hand side variables. The dependent variable is the ICRG internal conflict (a higher score means more internal political stability). Our hypothesis suggests that, ceteris paribus, corruption can be a destabilizing factor in countries with a relatively sizable youth population. To secure the ceteris paribus condition, in all models, we control for a group of variables that are discussed in the conflict literature. In Models 1.2 to 1.5, we also examine the competing hypotheses. Model 1.6 is our general specification in which we have our key independent variables, the competing interaction terms and the full set of control variables. We report the robust $t$-statistics for each estimated coefficient. Note that we use the one-year lag of all independent variables. Doing so helps reduce the reverse feedback and simultaneously takes into account the time gap for the manifestation of the independent variables' effects on political stability. In line with our theoretical expectation, the interaction term between corruption and youth is robust in its sign, size and significance in Models 1.1 to 1.6. Corruption becomes a challenging factor for internal stability in countries with a higher youth bulge.

In Models 1.2 to 1.5 , we add other interaction terms with youth that may moderate the stability effects of youth. In all these models, we keep our main interaction term of corruption and youth. It is interesting to observe that, even after controlling all these other competing hypotheses (as is discussed in Urdal, 2006), our interaction term remains robust. Even in Model 1.6, which has all of the control variables in the model, we observe that this is indeed the combined effect of corruption and youth, which is relevant for understanding the withincountry changes in stability in our sample.

Among the control variables, the most important driver of political (in)stability is youth unemployment. The effects of the other control variables are insignificant. 
The next step is to calculate the marginal impact of corruption on political stability at different levels of the youth bulge. Under which demographic structure may corruption buy instability and conflict? We use Equation 2 and Model 1.6 (as our general specification) to calculate the marginal stability effects of corruption.

We can calculate the critical level of the youth population (as a share of the adult population) beyond which corruption can fuel political instability:

$$
\frac{\partial\left(\operatorname{stab}_{i} i c r g_{i t}\right)}{\partial\left(\operatorname{cor}_{i t-1}\right)}=0.830-0.043 \cdot\left(\text { youth }_{i t-1}\right)=0
$$

The youth critical level $=0.830 / 0.043=19.30$. In countries in which the share of the youth population in the adult population exceeds $19.3 \%$, a one-unit increase in corruption promises political instability. Table A3 in the Appendix shows the included countries in the estimation of Model 1.6. Table A4 also shows the countries with higher perceptions of corruption, in which the youth bulge was higher than the calculated threshold in 2012.

In Table 2, we calculate the marginal stability effects of an increase in corruption at different levels (maximum, mean and minimum) of the youth bulge. The results show that a one-unit increase in the corruption index reduces the internal stability index by a score of 0.96 when the youth bulge is at its maximum. When the youth bulge is at its mean level, the same increase in corruption reduces the stability index by -0.33 . However, corruption may eventually buy stability (in line with the greasing hypothesis) when the youth bulge is at its minimum. 
Table 1. Political stability, corruption and youth:

Dependent variable: ICRG Political Stability (stab icrg)

\begin{tabular}{|c|c|c|c|c|c|c|}
\hline & $(1.1)$ & $(1.2)$ & $(1.3)$ & $(1.4)$ & $(1.5)$ & $(1.6)$ \\
\hline \multirow[t]{2}{*}{ L. wgi_corruption (reversed) } & 0.804 & 0.804 & $0.824^{*}$ & 0.763 & 0.777 & 0.830 \\
\hline & $(1.64)$ & $(1.64)$ & $(1.69)$ & $(1.56)$ & $(1.65)$ & $(1.57)$ \\
\hline \multirow[t]{2}{*}{ L. youth1524_15plus } & 0.020 & 0.020 & 0.020 & 0.040 & -0.036 & 0.019 \\
\hline & $(0.32)$ & $(0.31)$ & $(0.33)$ & $(0.57)$ & $(-0.35)$ & $(0.16)$ \\
\hline \multirow[t]{2}{*}{ L. wgi_corruption*youth1524_15plus } & $-0.044 * *$ & $-0.044 * *$ & $-0.045 * *$ & $-0.042 * *$ & $-0.044 * *$ & $-0.043 * *$ \\
\hline & $(-2.17)$ & $(-2.17)$ & $(-2.20)$ & $(-2.14)$ & $(-2.23)$ & $(-1.99)$ \\
\hline \multirow[t]{2}{*}{ L. van*youth1524_15plus } & & -0.000 & & & & 0.000 \\
\hline & & $(-0.01)$ & & & & $(0.09)$ \\
\hline \multirow[t]{2}{*}{ L. gdppcg*youth1524_15plus } & & & -0.001 & & & -0.001 \\
\hline & & & $(-0.86)$ & & & $(-1.06)$ \\
\hline \multirow[t]{2}{*}{ L. unempyouth*youth1524_15plus } & & & & -0.001 & & -0.001 \\
\hline & & & & $(-0.61)$ & & $(-0.46)$ \\
\hline \multirow[t]{2}{*}{ L. secondary*youth1524_15plus } & & & & & 0.001 & 0.001 \\
\hline & & & & & $(0.82)$ & $(0.81)$ \\
\hline \multirow[t]{2}{*}{ L. youth_unemployment } & $-0.029 * * *$ & $-0.029 * * *$ & $-0.028 * * *$ & -0.012 & $-0.028 * * *$ & -0.018 \\
\hline & $(-3.34)$ & $(-3.34)$ & $(-3.23)$ & $(-0.44)$ & $(-3.30)$ & $(-0.63)$ \\
\hline \multirow[t]{2}{*}{ L. population growth } & 0.018 & 0.018 & 0.018 & 0.020 & 0.014 & 0.023 \\
\hline & $(0.81)$ & $(0.81)$ & $(0.81)$ & $(0.91)$ & $(0.68)$ & $(0.21)$ \\
\hline \multirow[t]{2}{*}{ L. GDP per capita growth ( $g d p p c g)$} & 0.012 & 0.012 & 030 & 0.012 & 0.011 & 0.037 \\
\hline & $(1.48)$ & $(1.49)$ & $(1.53)$ & $(1.59)$ & $(1.34)$ & $(1.60)$ \\
\hline \multirow[t]{2}{*}{ L. fdi_gdp } & 0.001 & 0.001 & 0.001 & 0.001 & 0.001 & 0.002 \\
\hline & $(0.65)$ & $(0.65)$ & $(0.63)$ & $(0.73)$ & $(0.59)$ & $(1.23)$ \\
\hline \multirow[t]{2}{*}{ L. trade_gdp } & -0.004 & -0.004 & -0.004 & -0.004 & -0.004 & -0.002 \\
\hline & $(-1.25)$ & $(-1.25)$ & $(-1.28)$ & $(-1.29)$ & $(-1.20)$ & $(-0.69)$ \\
\hline \multirow[t]{2}{*}{ L. secondary_enrolment } & -0.002 & -0.002 & -0.002 & -0.002 & -0.015 & -0.016 \\
\hline & $(-0.40)$ & $(-0.40)$ & $(-0.41)$ & $(-0.42)$ & $(-1.01)$ & $(-1.00)$ \\
\hline \multirow[t]{2}{*}{ L. totalrent_gdp } & 0.001 & 0.001 & 0.002 & 0.001 & 0.001 & 0.007 \\
\hline & $(0.16)$ & $(0.16)$ & $(0.26)$ & $(0.13)$ & $(0.16)$ & $(0.71)$ \\
\hline \multirow[t]{2}{*}{ L. van_index } & 0.005 & 0.005 & 0.005 & 0.006 & 0.004 & 0.005 \\
\hline & $(0.66)$ & $(0.23)$ & $(0.67)$ & $(0.71)$ & $(0.44)$ & $(0.18)$ \\
\hline \multirow[t]{2}{*}{ L. gini_net } & & & & & & 0.006 \\
\hline & & & & & & $(0.20)$ \\
\hline Country fixed effects & Yes & Yes & Yes & Yes & Yes & Yes \\
\hline Year fixed effects & Yes & Yes & Yes & Yes & Yes & Yes \\
\hline Observations & 973 & 973 & 973 & 973 & 973 & 819 \\
\hline (within) R-sq & 0.18 & 0.18 & 0.19 & 0.19 & 0.19 & 0.18 \\
\hline
\end{tabular}

Note: Robust $t$-statistics are in parentheses. L. means a one-year lag in the independent variables. We have reversed the original wgi_corruption (by $*-1$ ): a higher wgi_corruption now shows higher corruption. ***,**, and $*$ indicate significance at the $1 \%, 5 \%$, and $10 \%$ levels, respectively. 
Table 2. Marginal stability effects of (lag) corruption at different levels of (lag) the youth bulge

Final stability effects of one score increase in (lag of) corruption at different levels of (lag of) youth bulge

$\begin{array}{llr}\text { Maximum of youth1524_15plus } & 41.73 & -0.964 \\ \text { Mean of youth1524_15plus } & 27.01 & -0.331 \\ \text { Minimum of youth1524_15plus } & 11.45 & 0.337\end{array}$

Note: the calculations are based on Model 1.6 in Table 1.

Figure 1. Marginal stability effects of corruption at different levels of the youth bulge (15-24 years of age/ 15 years of age and higher)

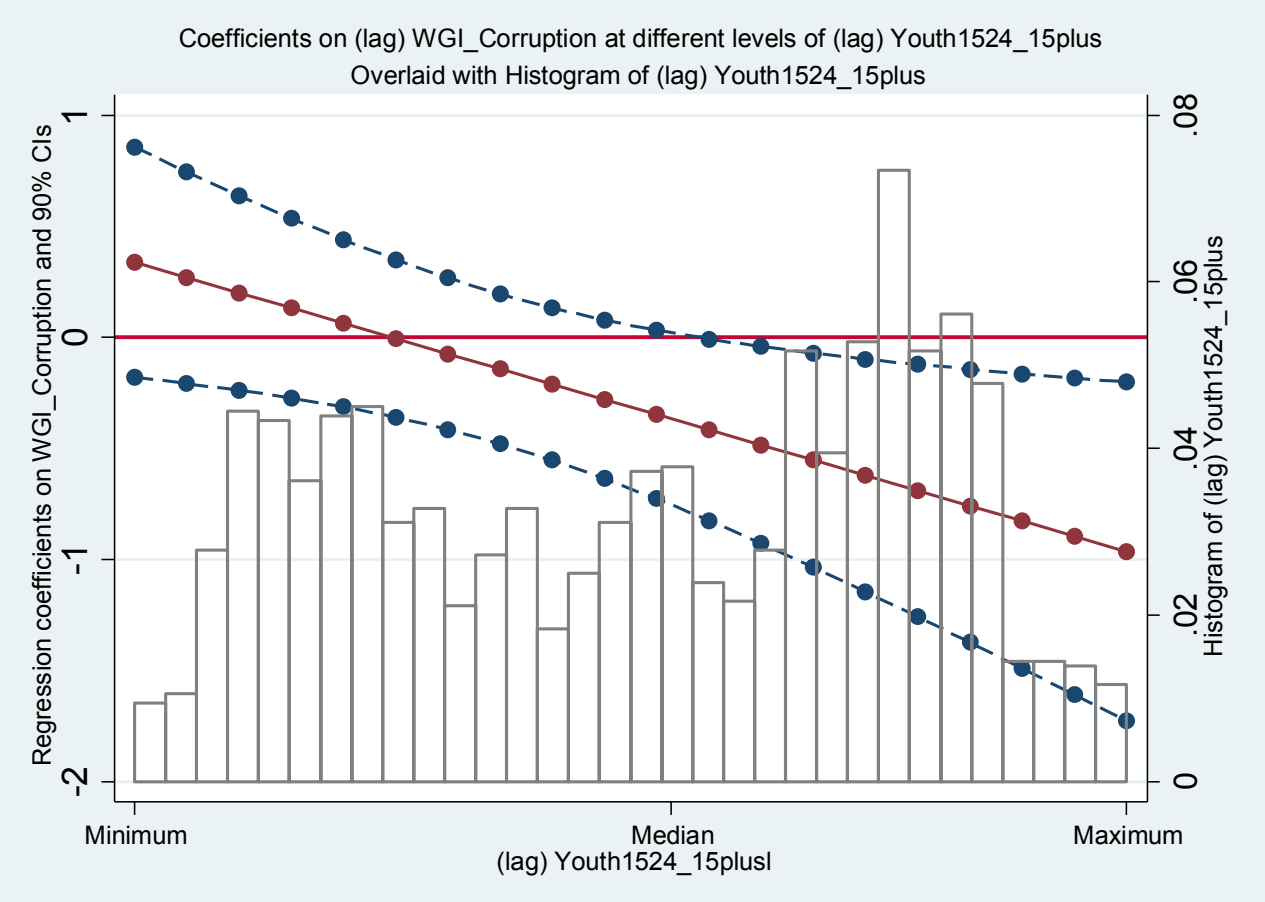

Note: solid middle line shows the marginal impacts and dashed lines are confidence intervals at $90 \%$ level. Calculations are based on Model 1.6 in Table 1.

However, to what extent are the calculated marginal impacts also significant? In Figure 1, we show the marginal stability effects of (the lag of) corruption at different levels of 
(the lag of) the youth bulge while reporting the confidence intervals around the marginal effects. The results show that the negative stability effects of corruption at higher levels of the youth bulge are also significant.

\section{Robustness checks}

Alternative operationalizations of the youth bulge

We have replicated our estimations in Table 1 by using the youth population (15-24 years of age) as a share of the total population. This alternative youth bulge proxy is critically reviewed by Urdal (2006). The results, which are in line with the previous findings in Table 1, are shown in Table 3 . Using the alternative definition, the stability effects of corruption significantly decrease in countries with a relatively higher size of the youth bulge. The interaction term between the youth bulge and corruption is negative in all specifications and significant at the 95\% and 99\% confidence intervals in Models 3.1-3.5. In Model 3.6, and by controlling for income inequality, the interaction term loses its significance but income inequality itself is also insignificant. Indeed, the inclusion of the Gini index has not increased the explanatory power of the model, as shown in the reduction in the adjusted R-squared in Model 3.6.

Another operationalization of the youth bulge in the literature examines the relative size of the population of 20-29 years of age. Some studies (e.g., Mehryar and Ahmad-Nia, 2006) classify those aged 15-19 as adolescents who need parental care and full-time education, whereas those aged 20-29 are defined as youths. This latter age group may be still in some formal education programs, but the majority of these individuals are looking for jobs and establishing their families. Thus, their relative size is a major concern for policy makers. We have calculated these indicators using disaggregated population data by age group from the World Bank databank of Population Estimates and Projections. Table 4 shows the results, using the share of the population 20-29 years of age in the total population 20 years of age 
and higher. The estimation results are highly consistent with the previous findings. We observe an even more robust effect of the interaction term between the new youth bulge variable and corruption on internal stability. More interestingly, we find that, even after controlling for income inequality (Model 4.6), the interaction term keeps its significance at the $95 \%$ confidence interval.

Finally, we check the results by using the share of the population 20-29 years of age in the adult population 15 years of age and higher. Our results are similar to the previous results. Again, our general specification, in which we have also controlled for income inequality, shows a robust negative and significant interaction term between corruption and our youth measure. The results are shown in Table 5. In summary, using different operationalization of the youth bulge supports our initial main findings, implying the destabilizing nature of corruption in countries with significant youth bulges. 
Table 3. Political stability, corruption and an alternative youth bulge (15-24 years of age/total population):

Dependent variable: ICRG Political Stability (stab_icrg)

\begin{tabular}{|c|c|c|c|c|c|c|}
\hline & $(3.1)$ & $(3.2)$ & $(3.3)$ & $(3.4)$ & $(3.5)$ & $(3.6)$ \\
\hline L. wgi_corruption (reversed) & $\begin{array}{l}1.371^{* *} \\
(2.11)\end{array}$ & $\begin{array}{l}1.309^{* *} \\
(2.01)\end{array}$ & $\begin{array}{l}1.397^{* *} \\
(2.16)\end{array}$ & $\begin{array}{l}1.319^{* *} \\
(2.06)\end{array}$ & $\begin{array}{l}1.196^{*} \\
(1.95)\end{array}$ & $\begin{array}{l}0.711 \\
(1.02)\end{array}$ \\
\hline L. youth1524_pop & $\begin{array}{l}0.053 \\
(0.76)\end{array}$ & $\begin{array}{l}0.024 \\
(0.28)\end{array}$ & $\begin{array}{l}0.053 \\
(0.77)\end{array}$ & $\begin{array}{l}0.090 \\
(1.06)\end{array}$ & $\begin{array}{l}-0.072 \\
(-0.46)\end{array}$ & $\begin{array}{l}0.000 \\
(0.00)\end{array}$ \\
\hline L. wgi_corruption*youth1524_pop & $\begin{array}{l}-0.096^{* *} \\
(-2.43)\end{array}$ & $\begin{array}{l}-0.093^{* *} \\
(-2.34)\end{array}$ & $\begin{array}{l}-0.097 * * \\
(-2.47)\end{array}$ & $\begin{array}{l}-0.093 * * \\
(-2.42)\end{array}$ & $\begin{array}{l}-0.087^{* *} \\
(-2.32)\end{array}$ & $\begin{array}{l}-0.055 \\
(-1.27)\end{array}$ \\
\hline L. van* youth1524_pop & & $\begin{array}{l}0.001 \\
(0.69)\end{array}$ & & & & $\begin{array}{l}0.001 \\
(0.37)\end{array}$ \\
\hline L. gdppcg*youth1524_pop & & & $\begin{array}{l}-0.002 \\
(-0.99)\end{array}$ & & & $\begin{array}{l}-0.001 \\
(-0.55)\end{array}$ \\
\hline L. unempyouth*youth1524_pop & & & & $\begin{array}{l}-0.002 \\
(-0.71)\end{array}$ & & $\begin{array}{l}-0.001 \\
(-0.35)\end{array}$ \\
\hline L. secondary*youth1524_pop & & & & & $\begin{array}{l}0.001 \\
(0.96)\end{array}$ & $\begin{array}{l}0.001 \\
(0.79)\end{array}$ \\
\hline L. youth_unemployment & $\begin{array}{l}-0.029^{* * *} \\
(-3.56)\end{array}$ & $\begin{array}{l}-0.029 * * * \\
(-3.59)\end{array}$ & $\begin{array}{l}-0.027 * * * \\
(-3.40)\end{array}$ & $\begin{array}{l}-0.002 \\
(-0.05)\end{array}$ & $\begin{array}{l}-0.027 * * * \\
(-3.41)\end{array}$ & $\begin{array}{l}-0.018 \\
(-0.46)\end{array}$ \\
\hline L. population growth & $\begin{array}{l}0.007 \\
(0.32)\end{array}$ & $\begin{array}{l}0.006 \\
(0.31)\end{array}$ & $\begin{array}{l}0.005 \\
(0.25)\end{array}$ & $\begin{array}{l}0.007 \\
(0.37)\end{array}$ & $\begin{array}{l}0.001 \\
(0.06)\end{array}$ & $\begin{array}{l}-0.002 \\
(-0.02)\end{array}$ \\
\hline L. GDP per capita growth ( $g d p p c g$ ) & $\begin{array}{l}0.010 \\
(1.37)\end{array}$ & $\begin{array}{l}0.010 \\
(1.35)\end{array}$ & $\begin{array}{l}0.043 \\
(1.40)\end{array}$ & $\begin{array}{l}0.011 \\
(1.49)\end{array}$ & $\begin{array}{l}0.010 \\
(1.28)\end{array}$ & $\begin{array}{l}0.030 \\
(0.81)\end{array}$ \\
\hline L. fdi_gdp & $\begin{array}{l}0.001 \\
(0.63)\end{array}$ & $\begin{array}{l}0.001 \\
(0.60)\end{array}$ & $\begin{array}{l}0.001 \\
(0.63)\end{array}$ & $\begin{array}{l}0.001 \\
(0.74)\end{array}$ & $\begin{array}{l}0.001 \\
(0.53)\end{array}$ & $\begin{array}{l}0.002 \\
(0.97)\end{array}$ \\
\hline L. trade_gdp & $\begin{array}{l}-0.004 \\
(-1.21)\end{array}$ & $\begin{array}{l}-0.004 \\
(-1.20)\end{array}$ & $\begin{array}{l}-0.004 \\
(-1.23)\end{array}$ & $\begin{array}{l}-0.004 \\
(-1.26)\end{array}$ & $\begin{array}{l}-0.004 \\
(-1.21)\end{array}$ & $\begin{array}{l}-0.002 \\
(-0.60)\end{array}$ \\
\hline L. secondary_enrolment & $\begin{array}{l}-0.001 \\
(-0.25)\end{array}$ & $\begin{array}{l}-0.002 \\
(-0.31)\end{array}$ & $\begin{array}{l}-0.001 \\
(-0.27)\end{array}$ & $\begin{array}{l}-0.002 \\
(-0.28)\end{array}$ & $\begin{array}{l}-0.023 \\
(-1.13)\end{array}$ & $\begin{array}{l}-0.021 \\
(-1.00)\end{array}$ \\
\hline L. totalrent_gdp & $\begin{array}{l}0.002 \\
(0.32)\end{array}$ & $\begin{array}{l}0.002 \\
(0.34)\end{array}$ & $\begin{array}{l}0.003 \\
(0.43)\end{array}$ & $\begin{array}{l}0.002 \\
(0.29)\end{array}$ & $\begin{array}{l}0.002 \\
(0.31)\end{array}$ & $\begin{array}{l}0.005 \\
(0.49)\end{array}$ \\
\hline L. van_index & $\begin{array}{l}0.005 \\
(0.58)\end{array}$ & $\begin{array}{l}-0.020 \\
(-0.57)\end{array}$ & $\begin{array}{l}0.005 \\
(0.59)\end{array}$ & $\begin{array}{l}0.005 \\
(0.64)\end{array}$ & $\begin{array}{l}0.003 \\
(0.35)\end{array}$ & $\begin{array}{l}-0.011 \\
(-0.26)\end{array}$ \\
\hline L. gini_net & & & & & & $\begin{array}{l}0.009 \\
(0.30)\end{array}$ \\
\hline Country fixed effects & Yes & Yes & Yes & Yes & Yes & Yes \\
\hline Year fixed effects & Yes & Yes & Yes & Yes & Yes & Yes \\
\hline $\begin{array}{l}\text { Observations } \\
\text { (within) R-sq }\end{array}$ & $\begin{array}{l}973 \\
0.19\end{array}$ & $\begin{array}{l}973 \\
0.19\end{array}$ & $\begin{array}{l}973 \\
0.19\end{array}$ & $\begin{array}{l}973 \\
0.19\end{array}$ & $\begin{array}{l}973 \\
0.19\end{array}$ & $\begin{array}{l}819 \\
0.18\end{array}$ \\
\hline
\end{tabular}

Note: Robust $t$-statistics are in parentheses. L. means a one-year lag in the independent variables. We have reversed the original wgi_corruption (by *-1): a higher wgi_corruption now shows higher corruption. ***, **, and $*$ indicate significance at the $1 \%, 5 \%$, and $10 \%$ levels, respectively 
Table 4. Political stability, corruption and an alternative youth bulge (20-29 years of age/20 years of age and higher):

Dependent variable: ICRG Political Stability (stab_icrg)

\begin{tabular}{|c|c|c|c|c|c|c|}
\hline & (4.1) & $(4.2)$ & (4.3) & $(4.4)$ & $(4.5)$ & (4.6) \\
\hline L. wgi_corruption (reversed) & $\begin{array}{l}1.041^{* *} \\
(1.99)\end{array}$ & $\begin{array}{l}1.091^{* *} \\
(2.18)\end{array}$ & $\begin{array}{l}1.083^{* *} \\
(2.08)\end{array}$ & $\begin{array}{l}0.983^{*} \\
(1.89)\end{array}$ & $\begin{array}{l}1.026^{* *} \\
(2.05)\end{array}$ & $\begin{array}{l}1.248^{* *} \\
(2.30)\end{array}$ \\
\hline L. youth2029_20plus & $\begin{array}{l}-0.009 \\
(-0.22)\end{array}$ & $\begin{array}{l}-0.024 \\
(-0.58)\end{array}$ & $\begin{array}{l}-0.007 \\
(-0.17)\end{array}$ & $\begin{array}{l}0.004 \\
(0.10)\end{array}$ & $\begin{array}{l}-0.095 \\
(-1.12)\end{array}$ & $\begin{array}{l}-0.056 \\
(-0.58)\end{array}$ \\
\hline L. wgi_corruption*youth2029_20plus & $\begin{array}{l}-0.047^{* *} \\
(-2.49)\end{array}$ & $\begin{array}{l}-0.049^{* * *} \\
(-2.66)\end{array}$ & $\begin{array}{l}-0.049^{* *} \\
(-2.56)\end{array}$ & $\begin{array}{l}-0.045^{* *} \\
(-2.41)\end{array}$ & $\begin{array}{l}-0.047 * * \\
(-2.60)\end{array}$ & $\begin{array}{l}-0.055^{* *} \\
(-2.60)\end{array}$ \\
\hline L. van* youth2029_20plus & & $\begin{array}{l}0.001 \\
(1.18)\end{array}$ & & & & $\begin{array}{l}0.001 \\
(1.04)\end{array}$ \\
\hline L. gdppcg*youth2029_20plus & & & $\begin{array}{l}-0.001 \\
(-0.94)\end{array}$ & & & $\begin{array}{l}-0.001 \\
(-1.13)\end{array}$ \\
\hline L. unempyouth*youth2029_20plus & & & & $\begin{array}{l}-0.001 \\
(-0.64)\end{array}$ & & $\begin{array}{l}-0.001 \\
(-0.79)\end{array}$ \\
\hline L. secondary*youth2029_20plus & & & & & $\begin{array}{l}0.001 \\
(1.33)\end{array}$ & $\begin{array}{l}0.001 \\
(1.03)\end{array}$ \\
\hline L. youth_unemployment & $\begin{array}{l}-0.030 * * * \\
(-3.31)\end{array}$ & $\begin{array}{l}-0.030 * * * \\
(-3.34)\end{array}$ & $\begin{array}{l}-0.029 * * * \\
(-3.21)\end{array}$ & $\begin{array}{l}-0.011 \\
(-0.39)\end{array}$ & $\begin{array}{l}-0.028^{* * *} \\
(-3.29)\end{array}$ & $\begin{array}{l}-0.006 \\
(-0.19)\end{array}$ \\
\hline L. population growth & $\begin{array}{l}0.003 \\
(0.08)\end{array}$ & $\begin{array}{l}0.008 \\
(0.26)\end{array}$ & $\begin{array}{l}-0.001 \\
(-0.04)\end{array}$ & $\begin{array}{l}0.000 \\
(0.01)\end{array}$ & $\begin{array}{l}-0.002 \\
(-0.06)\end{array}$ & $\begin{array}{l}0.058 \\
(0.50)\end{array}$ \\
\hline L. GDP per capita growth ( $g d p p c g$ ) & $\begin{array}{l}0.010 \\
(1.27)\end{array}$ & $\begin{array}{l}0.010 \\
(1.26)\end{array}$ & $\begin{array}{l}0.031 \\
(1.48)\end{array}$ & $\begin{array}{l}0.010 \\
(1.33)\end{array}$ & $\begin{array}{l}0.009 \\
(1.07)\end{array}$ & $\begin{array}{l}0.042 \\
(1.62)\end{array}$ \\
\hline L. fdi_gdp & $\begin{array}{l}0.002 \\
(0.84)\end{array}$ & $\begin{array}{l}0.002 \\
(0.79)\end{array}$ & $\begin{array}{l}0.002 \\
(0.83)\end{array}$ & $\begin{array}{l}0.002 \\
(0.94)\end{array}$ & $\begin{array}{l}0.001 \\
(0.71)\end{array}$ & $\begin{array}{l}0.002 \\
(1.07)\end{array}$ \\
\hline L. trade_gdp & $\begin{array}{l}-0.004 \\
(-1.19)\end{array}$ & $\begin{array}{l}-0.004 \\
(-1.17)\end{array}$ & $\begin{array}{l}-0.004 \\
(-1.23)\end{array}$ & $\begin{array}{l}-0.004 \\
(-1.19)\end{array}$ & $\begin{array}{l}-0.004 \\
(-1.18)\end{array}$ & $\begin{array}{l}-0.002 \\
(-0.62)\end{array}$ \\
\hline L. secondary_enrolment & $\begin{array}{l}-0.004 \\
(-0.69)\end{array}$ & $\begin{array}{l}-0.004 \\
(-0.81)\end{array}$ & $\begin{array}{l}-0.004 \\
(-0.70)\end{array}$ & $\begin{array}{l}-0.004 \\
(-0.74)\end{array}$ & $\begin{array}{l}-0.026^{*} \\
(-1.68)\end{array}$ & $\begin{array}{l}-0.023 \\
(-1.45)\end{array}$ \\
\hline L. totalrent_gdp & $\begin{array}{l}0.002 \\
(0.36)\end{array}$ & $\begin{array}{l}0.003 \\
(0.40)\end{array}$ & $\begin{array}{l}0.003 \\
(0.47)\end{array}$ & $\begin{array}{l}0.002 \\
(0.37)\end{array}$ & $\begin{array}{l}0.002 \\
(0.36)\end{array}$ & $\begin{array}{l}0.006 \\
(0.67)\end{array}$ \\
\hline L. van_index & $\begin{array}{l}0.006 \\
(0.73)\end{array}$ & $\begin{array}{l}-0.022 \\
(-0.95)\end{array}$ & $\begin{array}{l}0.006 \\
(0.75)\end{array}$ & $\begin{array}{l}0.006 \\
(0.78)\end{array}$ & $\begin{array}{l}0.004 \\
(0.48)\end{array}$ & $\begin{array}{l}-0.024 \\
(-0.84)\end{array}$ \\
\hline L. gini_net & & & & & & $\begin{array}{l}0.004 \\
(0.14)\end{array}$ \\
\hline Country fixed effects & Yes & Yes & Yes & Yes & Yes & Yes \\
\hline Yea fixed effects & Yes & Yes & Yes & Yes & Yes & Yes \\
\hline $\begin{array}{l}\text { Observations } \\
\text { (within) R-sq }\end{array}$ & $\begin{array}{l}973 \\
0.19\end{array}$ & $\begin{array}{l}973 \\
0.19\end{array}$ & $\begin{array}{l}973 \\
0.19\end{array}$ & $\begin{array}{l}973 \\
0.19\end{array}$ & $\begin{array}{l}973 \\
0.19\end{array}$ & $\begin{array}{l}819 \\
0.18\end{array}$ \\
\hline
\end{tabular}

Note: Robust t-statistics are in parentheses. L. means a one-year lag in the independent variables. We have reversed the original wgi_corruption (by $*-1)$ : a higher wgi_corruption now shows higher corruption. $* * *, * *$, and $*$ indicate significance at the $1 \%, 5 \%$, and $10 \%$ levels, respectively 
Table 5. Political stability, corruption and an alternative youth bulge (20-29 years of age/population 15 years of age and higher):

Dependent variable: ICRG Political Stability (stab_icrg)

\begin{tabular}{|c|c|c|c|c|c|c|}
\hline & $(5.1)$ & $(5.2)$ & $\begin{array}{l}(5.3) \\
\end{array}$ & $(5.4)$ & $(5.5)$ & $(5.6)$ \\
\hline L. wgi_corruption (reversed) & $\begin{array}{l}0.992 * \\
(1.75)\end{array}$ & $\begin{array}{l}1.085^{* *} \\
(2.04)\end{array}$ & $\begin{array}{l}1.039^{*} \\
(1.83)\end{array}$ & $\begin{array}{l}0.921 \\
(1.61)\end{array}$ & $\begin{array}{l}0.938^{*} \\
(1.74)\end{array}$ & $\begin{array}{l}1.340^{* *} \\
(2.21)\end{array}$ \\
\hline L. youth2029_15plus & $\begin{array}{l}-0.017 \\
(-0.41)\end{array}$ & $\begin{array}{l}-0.044 \\
(-1.03)\end{array}$ & $\begin{array}{l}-0.015 \\
(-0.36)\end{array}$ & $\begin{array}{l}-0.003 \\
(-0.07)\end{array}$ & $\begin{array}{l}-0.140 \\
(-1.33)\end{array}$ & $\begin{array}{l}-0.114 \\
(-0.97)\end{array}$ \\
\hline L. wgi_corruption*youth2029_15plus & $\begin{array}{l}-0.053^{* *} \\
(-2.20)\end{array}$ & $\begin{array}{l}-0.057^{* *} \\
(-2.49)\end{array}$ & $\begin{array}{l}-0.055^{* *} \\
(-2.27)\end{array}$ & $\begin{array}{l}-0.050^{* *} \\
(-2.07)\end{array}$ & $\begin{array}{l}-0.051^{* *} \\
(-2.24)\end{array}$ & $\begin{array}{l}-0.068^{* *} \\
(-2.43)\end{array}$ \\
\hline L. van* youth2029_15plus & & $\begin{array}{l}0.002 * \\
(1.77)\end{array}$ & & & & $\begin{array}{l}0.002 \\
(1.46)\end{array}$ \\
\hline L. gdppcg*youth2029_15plus & & & $\begin{array}{l}-0.001 \\
(-0.92)\end{array}$ & & & $\begin{array}{l}-0.001 \\
(-1.03)\end{array}$ \\
\hline L. unempyouth*youth2029_15plus & & & & $\begin{array}{l}-0.001 \\
(-0.53)\end{array}$ & & $\begin{array}{l}-0.001 \\
(-0.79)\end{array}$ \\
\hline L. secondary*youth2029_15plus & & & & & $\begin{array}{l}0.001 \\
(1.44)\end{array}$ & $\begin{array}{l}0.001 \\
(1.03)\end{array}$ \\
\hline L. youth_unemployment & $\begin{array}{l}-0.030^{* * *} \\
(-3.27)\end{array}$ & $\begin{array}{l}-0.030^{* * *} \\
(-3.31)\end{array}$ & $\begin{array}{l}-0.030^{* * *} \\
(-3.18)\end{array}$ & $\begin{array}{l}-0.012 \\
(-0.36)\end{array}$ & $\begin{array}{l}-0.029 * * * \\
(-3.24)\end{array}$ & $\begin{array}{l}-0.001 \\
(-0.04)\end{array}$ \\
\hline L. population growth & $\begin{array}{l}0.001 \\
(0.04)\end{array}$ & $\begin{array}{l}0.013 \\
(0.39)\end{array}$ & $\begin{array}{l}-0.004 \\
(-0.11)\end{array}$ & $\begin{array}{l}-0.001 \\
(-0.05)\end{array}$ & $\begin{array}{l}-0.002 \\
(-0.08)\end{array}$ & $\begin{array}{l}0.058 \\
(0.50)\end{array}$ \\
\hline L. GDP per capita growth ( $g d p p c g$ ) & $\begin{array}{l}0.010 \\
(1.20)\end{array}$ & $\begin{array}{l}0.010 \\
(1.22)\end{array}$ & $\begin{array}{l}0.033 \\
(1.37)\end{array}$ & $\begin{array}{l}0.010 \\
(1.23)\end{array}$ & $\begin{array}{l}0.008 \\
(1.02)\end{array}$ & $\begin{array}{l}0.043 \\
(1.42)\end{array}$ \\
\hline L. fdi_gdp & $\begin{array}{l}0.002 \\
(0.80)\end{array}$ & $\begin{array}{l}0.001 \\
(0.70)\end{array}$ & $\begin{array}{l}0.002 \\
(0.81)\end{array}$ & $\begin{array}{l}0.002 \\
(0.89)\end{array}$ & $\begin{array}{l}0.001 \\
(0.66)\end{array}$ & $\begin{array}{l}0.002 \\
(1.00)\end{array}$ \\
\hline L. trade_gdp & $\begin{array}{l}-0.004 \\
(-1.22)\end{array}$ & $\begin{array}{l}-0.004 \\
(-1.18)\end{array}$ & $\begin{array}{l}-0.004 \\
(-1.26)\end{array}$ & $\begin{array}{l}-0.004 \\
(-1.22)\end{array}$ & $\begin{array}{l}-0.004 \\
(-1.23)\end{array}$ & $\begin{array}{l}-0.002 \\
(-0.67)\end{array}$ \\
\hline L. secondary_enrolment & $\begin{array}{l}-0.004 \\
(-0.73)\end{array}$ & $\begin{array}{l}-0.005 \\
(-0.89)\end{array}$ & $\begin{array}{l}-0.004 \\
(-0.74)\end{array}$ & $\begin{array}{l}-0.004 \\
(-0.78)\end{array}$ & $\begin{array}{l}-0.031^{*} \\
(-1.79)\end{array}$ & $\begin{array}{l}-0.027 \\
(-1.47)\end{array}$ \\
\hline L. totalrent_gdp & $\begin{array}{l}0.003 \\
(0.43)\end{array}$ & $\begin{array}{l}0.003 \\
(0.44)\end{array}$ & $\begin{array}{l}0.004 \\
(0.53)\end{array}$ & $\begin{array}{l}0.003 \\
(0.45)\end{array}$ & $\begin{array}{l}0.003 \\
(0.43)\end{array}$ & $\begin{array}{l}0.006 \\
(0.66)\end{array}$ \\
\hline L. van_index & $\begin{array}{l}0.006 \\
(0.75)\end{array}$ & $\begin{array}{l}-0.040 \\
(-1.58)\end{array}$ & $\begin{array}{l}0.006 \\
(0.77)\end{array}$ & $\begin{array}{l}0.006 \\
(0.80)\end{array}$ & $\begin{array}{l}0.004 \\
(0.53)\end{array}$ & $\begin{array}{l}-0.045 \\
(-1.31)\end{array}$ \\
\hline L. gini_net & & & & & & $\begin{array}{l}0.004 \\
(0.13)\end{array}$ \\
\hline Country fixed effects & Yes & Yes & Yes & Yes & Yes & Yes \\
\hline Year fixed effects & Yes & Yes & Yes & Yes & Yes & Yes \\
\hline $\begin{array}{l}\text { Observations } \\
\text { (within) R-sq }\end{array}$ & $\begin{array}{l}973 \\
0.18\end{array}$ & $\begin{array}{l}973 \\
0.19\end{array}$ & $\begin{array}{l}973 \\
0.18\end{array}$ & $\begin{array}{l}973 \\
0.18\end{array}$ & $\begin{array}{l}973 \\
0.19\end{array}$ & $\begin{array}{l}819 \\
0.18\end{array}$ \\
\hline
\end{tabular}

Note: Robust t-statistics are in parentheses. L. means a one-year lag in the independent variables. We have reversed the original wgi_corruption (by $*-1$ ): a higher wgi_corruption now shows higher corruption. ***, **, and $*$ indicate significance at the $1 \%, 5 \%$, and $10 \%$ levels, respectively. 
In Figure 2, we show the marginal stability effects of (the lag of) corruption at different levels of (the lag of) the youth bulge, which is defined as the share of the population between 20-29 years of age in the population of 20 years of age and higher. This figure is based on the estimated specification of Model 4.6 in Table 4. We observe a pattern similar to that in Figure 1. The negative stability effect of corruption is visible and significant in countries with a larger size of the youth bulge.

Figure 2. Marginal stability effects of corruption at different levels of the youth bulge (20-29 years of age/20 years of age and higher)

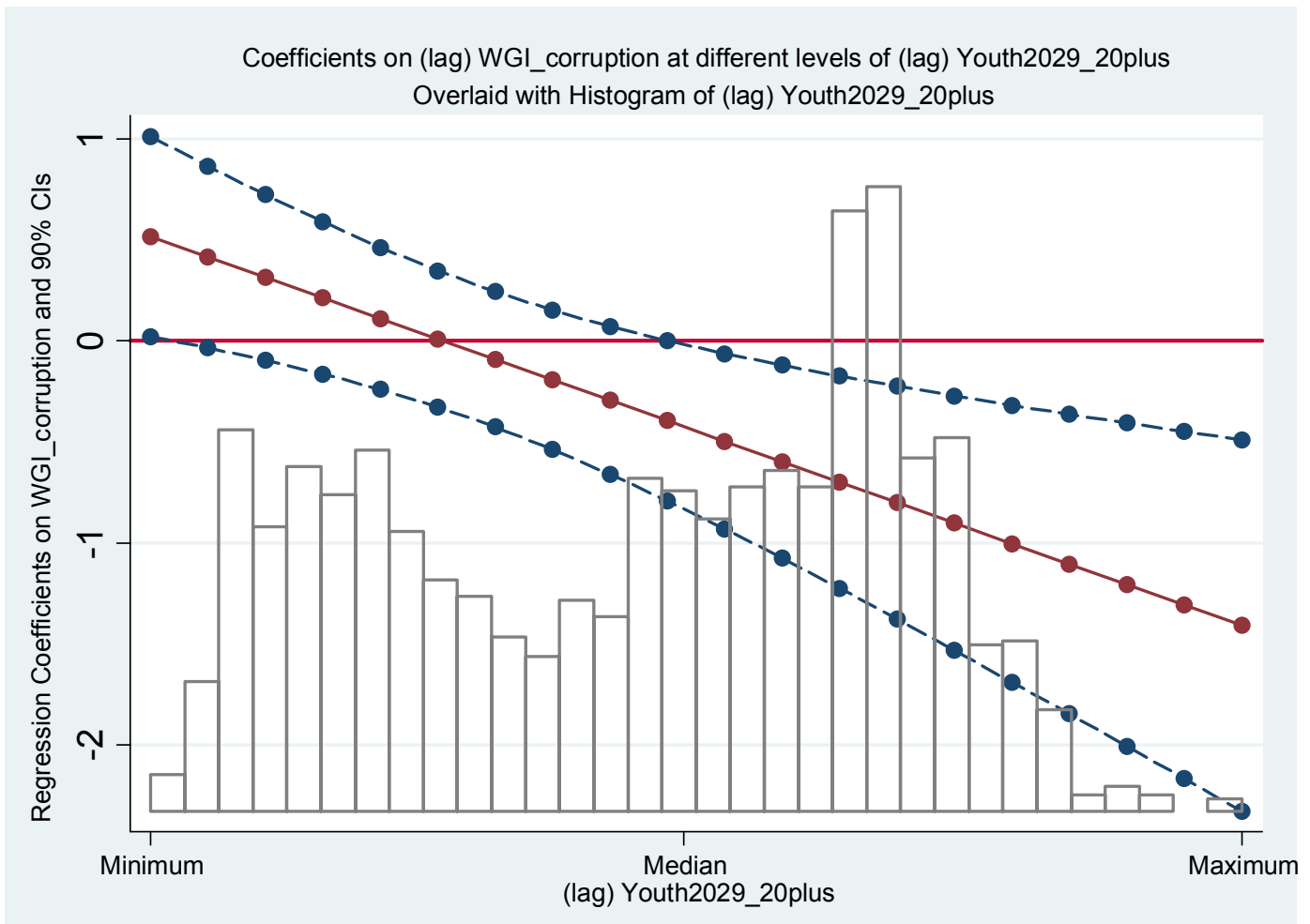

Note: solid middle line shows the marginal impacts and dashed lines are confidence intervals at $90 \%$ level. Calculations are based on Model 4.6 in Table 4.

\section{Issues of outliers}

Are our results presented in, for example, our general specification in Model 4.6 and the illustrated marginal impacts in Figure 2 due to outliers or influential observations? We examine the residuals to identify observations with a very large leverage or very large squared residuals. We follow the procedure in Bjorvatn and Farzanegan (2013). Following the 
identification of the large residuals, we apply the robust regression (Stata's rreg command), which gives lower weights to possible outliers (Hamilton, 1991). We re-estimate Model 4.6 by using pooled OLS with country and time fixed effects. In the next step, we use the $l v r 2 p l o t$ command, which produces a figure that shows the leverage versus the squared residuals. Following this step, we calculate the Cook's D and its cut-off, which is $4 /$ total observation in the estimated Model 4.6, namely, 819. Finally, to address outliers, we run the robust estimator. The results are shown in Table A5 in the Appendix. Our main results are qualitatively similar to the previous results. The significance of our main variables of interest is not affected by addressing outliers.

\section{Dynamic panel data estimation}

The previous results were based on static panel fixed effects. It is also likely that the current internal stability (as our dependent variable) is affected by its recent experience. Including the lag of internal stability as one of the predictors of current internal stability can increase the explanatory power of our estimation (see Beck and Katz, 1995). In addition, the lag of internal stability can also control for other possible variables for which we have not controlled but that may have an impact on current internal stability. With the presence of the lagged dependent variable, the standard fixed effects estimator becomes consistent only when the number of periods in the sample increases to infinity. In large N, small T samples such as that of our study (more than 150 countries and approximately 11 years), including the lagged dependent variable with fixed effects may lead to the so-called Nickell bias (see Nickell, 1981). Therefore, we estimate dynamic panel data that also address the endogeneity of the lagged dependent variable and a couple of other main variables of interest through internal instruments. For a robustness check, we re-estimate Model 1.1 of Table 1, using the two- and one-step generalized method of moments (GMM) system. This method is outlined by Arellano and Bover (1995) and developed by Blundell and Bond (1998). Blundell and Bond (1998) show that the GMM system estimator performs better than the first-difference GMM 
estimator in the presence of the persistent variables in the model (such as internal stability, corruption and the demographic indicators). By improving precision and reducing the finite sample bias, the GMM system produces more efficient estimates than the first-difference GMM method (Baltagi, 2008).

Table 6. Dynamic panel data estimation: Dependent variable: ICRG Political Stability (stab_icrg)

\begin{tabular}{|c|c|c|}
\hline & $(6.1)$ & $(6.2)$ \\
\hline & one-step system GMM & two-step system GMM \\
\hline \multirow[t]{2}{*}{ L. stab_icrg } & $0.775 * * *$ & $0.778 * * *$ \\
\hline & $(13.46)$ & $(9.91)$ \\
\hline \multirow[t]{2}{*}{ L. wgi_corruption (reversed) } & $0.528 *$ & 0.603 \\
\hline & $(1.73)$ & $(1.54)$ \\
\hline \multirow[t]{2}{*}{ L. youth1524_15plus } & -0.015 & -0.019 \\
\hline & $(-0.77)$ & $(-0.65)$ \\
\hline \multirow[t]{2}{*}{ L. wgi_corruption*youth1524_15plus } & $-0.039 * *$ & $-0.044^{*}$ \\
\hline & $(-2.30)$ & $(-1.87)$ \\
\hline \multirow[t]{2}{*}{ L. youth_unemployment } & -0.009 & -0.005 \\
\hline & $(-1.15)$ & $(-0.63)$ \\
\hline \multirow[t]{2}{*}{ L. population growth } & -0.067 & -0.076 \\
\hline & $(-1.25)$ & $(-1.19)$ \\
\hline \multirow[t]{2}{*}{ L. GDP per capita growth ( $g d p p c g$ ) } & -0.013 & -0.017 \\
\hline & $(-0.86)$ & $(-0.98)$ \\
\hline \multirow[t]{2}{*}{ L. fdi_gdp } & -0.008 & -0.009 \\
\hline & $(-0.77)$ & $(-0.92)$ \\
\hline \multirow[t]{2}{*}{ L. trade_gdp } & 0.003 & 0.003 \\
\hline & $(1.14)$ & $(1.23)$ \\
\hline \multirow[t]{2}{*}{ L. secondary_enrolment } & -0.009 & -0.011 \\
\hline & $(-1.54)$ & $(-1.21)$ \\
\hline \multirow[t]{2}{*}{ L. totalrent_gdp } & 0.014 & $0.018^{*}$ \\
\hline & $(1.44)$ & $(1.85)$ \\
\hline \multirow[t]{2}{*}{ L. van_index } & 0.011 & 0.008 \\
\hline & $(1.32)$ & $(0.84)$ \\
\hline Observations & 972 & 972 \\
\hline Countries & 124 & 124 \\
\hline Number of instruments & 74 & 74 \\
\hline Hansen test (p-value) & 0.149 & 0.149 \\
\hline AR(1)- $p$ value & 0.000 & 0.000 \\
\hline AR(2)- p-value & 0.360 & 0.408 \\
\hline
\end{tabular}

Note: Robust $t$ statistics are in parentheses. L. means a one year lag in the independent variables. We have reversed the original wgi_corruption (by $*_{-}-1$ ): a higher wgi_corruption shows higher corruption. Year fixed effects are included. To estimate the system GMM specifications, we use the xtabond2 procedure which is presented in details by Roodman (2009). ***,**, and * indicate significance at the $1 \%, 5 \%$, and $10 \%$ levels, respectively. 
The GMM system method uses lagged values of the explanatory variables (in levels and differences) to instrument the potential endogenous variables. We treat lagged internal stability, lagged corruption, lagged youth (based on the definition by Urdal), and the lagged interaction term as endogenous variables and use a two-year lag of the variables as instruments. Our instruments must not be correlated with the error term. To test the validity of our internal instruments, we check the Hansen statistic. The second-order serial correlation statistics are also examined. We expect to reject the existence of the second-order serial correlation, especially if our instruments are valid (Bjorvatn and Farzanegan, 2013). Following Roodman (2009), we also use orthogonal deviations and apply robust standard errors that are consistent with panel-specific autocorrelation and heteroskedasticity. Table 6 shows the estimation of the GMM system (one- and two-step) of our baseline specification (presented in Table 1, Model 1.1).

The results are in line with fixed effects regressions. The negative interaction term between corruption and youth survives even after controlling for lagged internal stability. Both the Hansen test of over-identification restrictions and the second-order serial correlation test are satisfactory, i.e., the internal instruments are valid and the estimations are consistent (we can reject the second-order serial correlation).

\section{4- Conclusion}

We investigate how the impact of increases in corruption on political stability may be contingent on the relative size of the youth bulge. To test this hypothesis, we employ panel data covering the 2002-2012 period and more than 100 countries. Our theoretical argument is supported by the data. In particular, the stability effects of corruption decrease with higher levels of the youth population (15-24 years of age) in the adult population (15 years of age and higher). Corruption is a destabilizing factor for political systems when the share of the youth population in the adult population exceeds the threshold level of approximately $19 \%$. 
Our main results hold when we control for the effects of economic growth, youth unemployment, democracy, population growth, the share of FDI (foreign direct investment) in the GDP, trade openness, secondary school enrolment rate, total natural resource rents in the GDP, income inequality, and country and year fixed effects. We also show that our main interaction term of corruption and youth remains robust when we control for other competing channels of the stability effects of youth, as suggested by Urdal (2006). A combination of increasing corruption and the demographic burden of youth is a ticking time bomb like we have already experienced in the political re-configuration in the Middle East and North Africa since 2011.

Our results have policy implications regarding anti-corruption reforms aimed at improving internal political stability. In the case of limited funds for such reforms, they should be used effectively, i.e., where the youth bulge is high. 


\section{References}

Aidt, T.S., 2009. Corruption, institutions, and economic development. Oxford Review of Economic Policy 25, 271-291.

Aidt, T.S., Leon, G., 2015. The democratic window of opportunity evidence from riots in subSaharan Africa. Journal of Conflict Resolution. doi: 10.1177/0022002714564014

Alesina, A., Perotti, R., 1996. Income distribution, political instability, and investment. European Economic Review 40, 1203-28.

Anbarci, N., Escalares, M., Register, C.A., 2009. The ill effects of public sector corruption in the water and sanitation sector. Land Economics 85, 363-377.

Arellano, M., Bover, O., 1995. Another look at the instrumental variable estimation of errorcomponents models. Journal of Econometrics 68, 29-51.

Azeng, T.F., Yogo, T., 2013. Youth unemployment and political instability in selected developing countries. Working Paper Series N 171, African Development Bank, Tunis, Tunisia.

Baltagi, B. H., 2008. Econometric analysis of panel data (4th Ed.). Chichester: Wiley.

Barakat, B., Urdal, H., 2009. Breaking the waves? Does education mediate the relationship between youth bulges and political violence? Policy Research Working Papers. The World Bank.

Barbieri, K., Schneider, G., 1999. Globalization and peace: assessing new directions in the study of trade and conflict. Journal of Peace Research 36, 387-404.

Beck, N., Katz, J.N., 1995. What to do (and not to do) with time-series cross-section data. American Political Science Review 89, 634-647.

Besley, T., Prat, A., 2006. Handcuffs for the grabbing hand? Media capture and government accountability. American Economic Review 96, 720-736.

Biswas, A.K., Farzanegan, M.R., Thum, M., 2012. Pollution, shadow economy and corruption: theory and evidence. Ecological Economics 75, 114-25.

Bjorvatn, K., Farzanegan, M.R., 2015. Resource rents, balance of power, and political stability. Journal of Peace Research 52, 758-773.

Bjorvatn, K., Farzanegan, M.R., 2013. Demographic transition in resource rich countries: a blessing or a curse? World Development 45, 337-351.

Bjorvatn, K., Farzanegan, M.R., Schneider, F., 2012. Resource curse and power balance: evidence from oil-rich countries. World Development 40, 1308-1316

Blackburn, K., Sarmah, R., 2008. Corruption, development and demography. Economics of Governance 9, 341-62.

Blundell, R., Bond, S., 1998. Initial conditions and moment restrictions in dynamic panel data models. Journal of Econometrics 87, 115-43.

Bricker, N. Q., Foley, M. C., 2013. The effect of youth demographics on violence: the importance of the labor market. International Journal of Conflict and Violence 7, 179-194.

Brückner, M., Ciccone, A., 2011. Rain and the democratic window of opportunity. Econometrica 79, 923-947. 
Brückner, M., Gradstein, M., 2015. Income growth, ethnic polarization, and political risk: Evidence from international oil price shocks. Journal of Comparative Economics $43,575-594$.

Brunetti, A., Weder, B., 2003. A free press is bad news for corruption. Journal of Public Economics 87, 1801-24.

Buehn, A., Farzanegan, M.R., 2013. Impact of education on the shadow economy: Institutions matter. Economics Bulletin 33, 2052-2063.

Burke, P.J., Leigh, A., 2010. Do output contractions trigger democratic change? American Economic Journal: Macroeconomics 2, 124-57.

Collier, P., 2000. Doing well out of war: an economic perspective. In: Berdal, M. , Malone, D.M. (Eds.), Greed and Grievance: Economic Agendas in Civil Wars. Boulder, CO and London: Lynne Rienner, pp. 91-111.

Collier, P., Hoeffler, A., 1998. On economic causes of civil war. Oxford Economic Papers 50, 563-573.

Collier, P., Hoeffler, A., 2004. Greed and grievance in civil war. Oxford Economic Papers 56, 563-595.

Dahl, R. A., 1971. Polyarchy: Participation and Opposition. New Haven and London: Yale University Press.

de Groeve, T., Vernaccini, L., Hachemer, P., 2014. The global conflict risk index (GCRI): a quantitative model. Office of the European Union Nr. JRC92293, doi $10.2788 / 184$

de Soysa, I., 2002. Paradise is a bazaar? Greed, creed, and governance in civil war, 1989-99. Journal of Peace Research 39, 395-416.

Diwan, I., 2013. Understanding revolution in the Middle East: the central role of the middle class. Middle East Development Journal 05, 1-30.

Diuk, N., 2013. Youth as an agent for change: the next generation in Ukraine. Demokratizatsiya 21, 179-196.

Dorsch, M.T., Dunz, K., Maarek, P., 2015. Macro shocks and costly political action in nondemocracies. Public Choice 162, 381-404.

Dreher, A., Gassebner, M., 2013. Greasing the wheels? The impact of regulations and corruption on firm entry. Public Choice 155, 413-432.

Dreher, A., Herzfeld, T., 2008. The economic costs of corruption: a survey and new evidence. Annals of the IVth Global Forum on Fighting Corruption, Office of the Comptroller General of Brazil, 263-292.

Fearon, J. D., Laitin, D. D., 2003. Ethnicity, insurgency, and civil war. American Political Science Review 97, 75-90.

Fisman, R., Miguel, E., 2007. Corruption, norms, and legal enforcement: evidence from diplomatic parking tickets. Journal of Political Economy 115, 1020-1048.

Fisman, R., Wie, S-J., 2009. The smuggling of art, and the art of smuggling: uncovering the illicit trade in cultural property and antiques. American Economic Journal: Applied Economics 1, 82-96.

Fjelde, H., 2009. Buying peace? Oil wealth, corruption and civil war, 1985-99. Journal of Peace Research 46, 199-218. 
Fredriksson, P.G., Svensson, J., 2003. Political instability, corruption and policy formation: the case of environmental policy. Journal of Public Economics 87, 1383-1405.

Fuller, G. E., 1995. The demographic backdrop to ethnic conflict: a geographic overview. In: Central Intelligence Agency (Ed.), The Challenge of Ethnic Conflict to National and International Order in the 1990's, Washington DC: CIA (RTT 9510039), pp. 151-154.

Gates, S., Nygård, H. M., Strand, H., 2012. Development consequences of armed conflict, World Development 40, 1713-1722.

Gaub, F., 2012. Understanding instability: Lessons from the 'Arab Spring'. Spring'Report for the 'History of British Intelligence and Security' research project. Arts and Humanities Research Council.

Gleditsch, N. P., Wallensteen, P., Eriksson, M., Sollenberg, M., Strand, H., 2002. Armed conflict 1946-2001: a new dataset. Journal of Peace Research 39, 615-637.

Goldstone, J., 2002. Population and security: how demographic change can lead to violent conflict. Journal of International Affairs 56, 3-21.

Goldstone, J., 2001. Demography, environment, and security. In: Paul F. Diehl and Nils Petter Gleditsch, eds., Environmental Conflict. Boulder, CO: Westview, pp. 84108.

Goldstone, J., 1991. Revolution and rebellion in the early modern world. Berkeley: University of California Press.

Gupta, S., Clements, B., Bhattacharya, R., Chakravarti, S., 2004. Fiscal consequences of armed conflict and terrorism in low- and middle-income countries. European Journal of Political Economy 20, 403-421.

Gupta, S., Davoodi, H., Alonso-Terme, R., 2002. Does corruption affect income inequality and poverty? Economics of Governance 3, 23-45.

Gupta, S., Davoodi, H., Tiongson, E., 2001. Corruption and the provision of health care and education services. In: Jain, A. K. (Ed.), The Political Economy of Corruption. Routledge, London; New York, pp. 111-141.

Hamilton, L. C., 1991. How robust is robust regression? Stata Technical Bulletin 2, 21-26.

Heinsohn, G., 2006. 'Demography and War'. Presentation at the city defence forum roundtable. Available at: http://davidbau.com/downloads/heinsohn_slides.pdf

Heinsohn, G., 2007. Islamism and war: the demographics of rage. Open Democracy, July. Available

at:

https://www.opendemocracy.net/conflicts/democracy_terror/islamism_war_demo graphics_rage

Hendrix, C., Salehyan, I., 2012. Climate change, rainfall, and social conflict in Africa. Journal of Peace Research 49, 35-50.

Hsiang, S., Meng, K., Cane, M., 2011. Civil conflicts are associated with global climate. Nature 476, 438-441.

Huntington, S. P., 1996. The clash of civilizations and the remaking of world order. New York: Simon \& Schuster.

Huntington, S. P., 1968. Political order in changing societies. Yale University Press.

ICRG, 2015. International Country Risk Guide. The PRS Group, New York. 
Jinjarak, Y., 2009. Trade variety and political conflict: Some international evidence. Economics Letters 103, 26-28.

Kahl, C.H., 1998. Population growth, environmental degradation, and state-sponsored violence: The case of Kenya, 1991-93. International Security 23, 80-119.

Kahl, C. H., 2006. States, Scarcity, and Civil Strife in the Developing World. Princeton and Oxford: Princeton University Press.

Kato, A., Sato, T., 2015. Greasing the wheels? The effect of corruption in regulated manufacturing sectors of India. Canadian Journal of Development Studies/ Revue canadienne d'études du développement, DOI: 10.1080/02255189.2015.1026312

Kaufmann, D., Kraay, A., Mastruzzi, M., 2010. The Worldwide Governance Indicators: Methodolo-gy and Analytical Issues. World Bank Policy Research Working Paper No. 5430.

Lambsdorff, J.G., 2007. The institutional economics of corruption and reform: theory, evidence, and policy. Cambridge University Press.

Leff, N., 1964. Economic development through bureaucratic corruption. American Behavioural Scientist 8, 8-14.

Lessmann, C., 2016. Regional inequality and conflict. German Economic Review 17, 157191.

Long, A.G., 2008. Bilateral trade in the shadow of armed conflict. International Studies Quarterly 52, 1468-1478.

Mauro, P., 1995. Corruption and growth. The Quarterly Journal of Economics 110, 681-712.

Mehryar, A. H., Ahmad-Nia, S., 2006. Age-structural transition in Iran: short- and long-term consequences of drastic fertility swings during the final decades of the twentieth century. In: Pool, I., Wong, L.R., Vilquin, E. (Eds.), Age-Structural Transitions: Challenges for Development. Committee for International Cooperation in National Research in Demography, Paris, pp 319-358.

Méon, P.G., Weill, L., 2010. Is corruption an efficient grease? World Development 38, 244 259.

Mo, P. H., 2001. Corruption and economic growth. Journal of Comparative Economics 29, 66-79.

Nesvaderani, T., Memarian, O., 2010. Iran's youth: agents of change. USIP Peace Brief 51, 15.

Neudorfer, N.S., Theuerkauf, U.G., 2014. Buying war not peace: the influence of corruption on the risk of ethnic war. Comparative Political Studies 47, 1856-1886.

Neumayer, E., 2004. The impact of political violence on tourism: Dynamic cross national estimation. Journal of Conflict Resolution 48, 259-281.

Nickell, S., 1981. Biases in dynamic models with fixed effects. Econometrica 49, 1417-1426.

Nordås, R., Davenport, C., 2013. Fight the youth: youth bulges and state repression. American Journal of Political Science 57, 926-940

Onuoha, F.C., 2014. Why do youth join Boko Haram? The United States Institute of Peace Special Report No. 348, Washington D.C.

Roodman, D., 2009. How to do xtabond2: an introduction to "difference" and "system" GMM in Stata. Stata Journal 9, 86-136. 
Sigelman, L., Simpson, M., 1977. Cross-national test of linkage between economic inequality and political violence. Journal of Conflict Resolution 21, 105-128.

Solt, F., 2009. Standardizing the World Income Inequality Database. Social Science Quarterly 90, 231-242.

Sung, H.-E., 2002. A convergence approach to the analysis of political corruption: a crossnational study. Crime, Law and Social Change 38, 137-160.

Themnér, L., Wallensteen, P., 2014. Armed conflict, 1946-2013. Journal of Peace Research $51,541-554$.

Urdal, H., 2006. A clash of generations? Youth bulges and political violence. International Studies Quarterly 50, 607-629.

Urdal, H., 2004. The devil in the demographics: The effect of youth bulges on domestic armed conflict, 1950-2000. Social Development Papers, Conflict Prevention \& Reconstruction. Washington, D.C.: World Bank.

Urdal, H., 2012. A clash of generations? Youth bulges and political violence. Expert Paper No. 2012/1. United Nations Department of Economic and Social Affairs, United Nations New York.

Vanhanen, T., 2000. A new dataset for measuring democracy, 1810-1998". Journal of Peace Research 37, 251-265.

Vial, V., Hanoteau, J., 2010. Corruption, manufacturing plant growth and the Asian paradox: micro-level evidence from Indonesia. World Development 38, 693-705.

Weber, H., 2013. Demography and democracy: the impact of youth cohort size on democratic stability in the world. Democratization 20, 335-357.

Wooldridge, J. M., 2002. Econometric analysis of cross section and panel data. Cambridge, MA: MIT Press.

World Bank, 2015. World Development Indicators. Washington D.C.

Yousef, T., 2003. Youth in the Middle East and North Africa: demography, employment, and conflict. In: Ruble, B. A., Tulchin, J. S., Varat, D. H., Hanley, L. M. (Eds.), Youth Explosion in Developing World Cities. Woodrow Wilson International Center for Scholars, Washington, D.C, pp. 9-24. 


\section{Appendix}

Table A1. Summary statistics of the main variables

\begin{tabular}{lllllll}
\hline \hline Variables & & Mean & S.D. & Min. & Max. & Obs. \\
\hline ICRG Stability (stab_icrg) & & & & & & \\
& overall & 9.32 & 1.65 & 2.92 & 12.00 & $\mathrm{~N}=1530$ \\
& between & & 1.50 & 3.94 & 12.00 & $\mathrm{n}=140$ \\
& within & & 0.69 & 5.21 & 13.12 & $\mathrm{~T}-\mathrm{bar}=10.92$ \\
\hline WGI_Corruption (reversed cor_wgi) & & & & & & \\
& overall & 0.07 & 1.01 & -2.55 & 1.92 & $\mathrm{~N}=2064$ \\
& between & & 0.99 & -2.45 & 1.71 & $\mathrm{n}=189$ \\
& within & & 0.17 & -0.81 & 0.90 & $\mathrm{~T}-\mathrm{bar}=10.92$ \\
\hline Youth1524_15plus & & & & & & \\
& overall & 26.88 & 8.16 & 11.29 & 42.10 & $\mathrm{~N}=2090$ \\
& between & & 8.10 & 11.96 & 40.96 & $\mathrm{n}=190$ \\
& within & & 1.15 & 19.97 & 31.33 & $\mathrm{~T}=11$ \\
\hline Youth1524_totalpop & & & & & & \\
& overall & 17.97 & 3.35 & 9.78 & 26.26 & $\mathrm{~N}=2090$ \\
& between & & 3.28 & 10.28 & 24.02 & $\mathrm{n}=190$ \\
& within & & 0.71 & 13.35 & 21.90 & $\mathrm{~T}=11$ \\
\hline WGI_corruption*Youth1524_15plus & & & & & & \\
& overall & 7.41 & 24.28 & -45.69 & 68.79 & $\mathrm{~N}=2064$ \\
& between & & 23.86 & -43.05 & 61.05 & $\mathrm{n}=189$ \\
& within & & 5.08 & -18.62 & 34.41 & $\mathrm{~T}-\mathrm{bar}=10.92$ \\
& & & & & & \\
& overall & 3.43 & 16.48 & -36.07 & 39.06 & $\mathrm{~N}=2064$ \\
& between & & 16.21 & -33.95 & 31.95 & $\mathrm{n}=189$ \\
& within & & 3.29 & -11.18 & 19.58 & $\mathrm{~T}$-bar $=10.92$ \\
\hline \hline
\end{tabular}




\begin{tabular}{|c|c|}
\hline Variable & Definition and source \\
\hline stab_icrg & $\begin{array}{l}\text { This is an assessment of political violence in the country and its } \\
\text { actual or potential impact on governance. The highest rating is } \\
\text { given to those countries where there is no armed or civil } \\
\text { opposition to the government and the government does not } \\
\text { indulge in arbitrary violence, direct or indirect, against its own } \\
\text { people. The lowest rating is given to a country embroiled in an } \\
\text { on-going civil war. The risk rating assigned is the sum of three } \\
\text { subcomponents, each with a maximum score of four points and a } \\
\text { minimum score of } 0 \text { points. A score of } 4 \text { points equates to Very } \\
\text { Low Risk and a score of } 0 \text { points to Very High Risk. The three } \\
\text { elements in this index are: Civil War/Coup Threat, } \\
\text { Terrorism/Political Violence, Civil Disorder. Its range is from } 0 \\
\text { to 12. The higher score means lower internal conflict or higher } \\
\text { internal stability. Source: ICRG (2015) }\end{array}$ \\
\hline wgi_corruption & $\begin{array}{l}\text { Reversed version of World Governance Indicators Corruption } \\
\text { index. It "captures perceptions of the extent to which public } \\
\text { power is exercised for private gain, including both petty and } \\
\text { grand forms of corruption, as well as "capture" of the state by } \\
\text { elites and private interests". The WGI_Corruption is from about - } \\
2.5 \text { to } 2.5 \text {. Higher scores in this revised index means more } \\
\text { corruption. } \\
\text { catalog/worldwide-governance-indicators }\end{array}$ \\
\hline youth1524_15plus & $\begin{array}{l}\text { The share of youth population ( } 15 \text { to } 24 \text { years }) \text { in adult } \\
\text { population }(15+) \text {. Source: http://data.worldbank.org/data- } \\
\text { catalog/population-projection-tables }\end{array}$ \\
\hline youth_unemployment & $\begin{array}{l}\text { Unemployment, youth total ( } \% \text { of total labor force ages } 15-24 \text { ) } \\
\text { (modeled ILO estimate). Youth unemployment refers to the share } \\
\text { of the labor force ages } 15-24 \text { without work but available for and } \\
\text { seeking employment. Source: World Bank (2015) }\end{array}$ \\
\hline population growth & $\begin{array}{l}\text { Population growth (annual \%) is the exponential rate of growth } \\
\text { of midyear population from year } t-1 \text { to } t \text {, expressed as a } \\
\text { percentage. Source: World Bank }(2015)\end{array}$ \\
\hline GDP per capita growth & $\begin{array}{l}\text { Annual percentage growth rate of GDP per capita based on } \\
\text { constant local currency. Aggregates are based on constant } 2005 \\
\text { U.S. dollars. Source: World Bank (2015) }\end{array}$ \\
\hline fdi_gdp & $\begin{array}{l}\text { Foreign direct investment, net inflows ( } \% \text { of GDP). Source: } \\
\text { World Bank (2015) }\end{array}$ \\
\hline trade_gdp & $\begin{array}{l}\text { Trade is the sum of exports and imports of goods and services } \\
\text { measured as a share of gross domestic product. Source: World } \\
\text { Bank (2015) }\end{array}$ \\
\hline secondary_enrolment & $\begin{array}{l}\text { Gross enrolment ratio. Secondary. All programmes. Total is the } \\
\text { total enrollment in secondary education, regardless of age, } \\
\text { expressed as a percentage of the population of official secondary } \\
\text { education age. Source: World Bank (2015) }\end{array}$ \\
\hline \multirow[t]{2}{*}{ totalrent_gdp } & Total natural resources rents ( $\%$ of GDP). \\
\hline & $\begin{array}{l}\text { Total natural resources rents are the sum of oil rents, natural gas } \\
\text { rents, coal rents (hard and soft), mineral rents, and forest rents. } \\
\text { Source: World Bank (2015) }\end{array}$ \\
\hline van_index & $\begin{array}{l}\text { Vanhanen index } \\
\text { http://www.fsd.uta.fi/en/data/catalogue/FSD1289/meF1289e.html }\end{array}$ \\
\hline gini_net & $\begin{array}{l}\text { Net income inequality (post tax, post transfer). Source: Solt } \\
(2009)\end{array}$ \\
\hline
\end{tabular}


Table A3. Names of the countries in the estimation of Model 1.6 in Table 1

\begin{tabular}{|c|c|c|c|c|c|c|c|c|}
\hline Albania & Algeria & Angola & Argentina & Armenia & Australia & Austria & Azerbaijan & Bahamas \\
\hline Bangladesh & Belarus & Belgium & Bolivia & Botswana & Bulgaria & Burkina Faso & $\begin{array}{l}\text { Cameroon" } \\
\text { Czech }\end{array}$ & Canada \\
\hline $\begin{array}{l}\text { Chile } \\
\text { Dominican }\end{array}$ & China & $\begin{array}{l}\text { Colombia } \\
\text { Egypt Arab }\end{array}$ & Costa Rica & Cote d'Ivoire & Croatia & Cyprus & Republic & Denmark \\
\hline Republic & Ecuador & Rep. & El-Salvador & Estonia & Ethiopia & Finland & France & Germany \\
\hline Ghana & $\begin{array}{l}\text { Greece } \\
\text { Iran Islamic }\end{array}$ & Guatemala & Guinea & Guinea-Bissau & Honduras & Hungary & Iceland & India \\
\hline Indonesia & Rep. & Ireland & Israel & Italy & Japan & Jordan & Kazakhstan & Kenya \\
\hline Korea Rep. & Latvia & Lebanon & Lithuania & Luxembourg & Madagascar & Malawi & Malaysia & Mali \\
\hline Malta & Mexico & Moldova & Mongolia & Morocco & Mozambique & Namibia & Netherlands & New Zealand \\
\hline Nicaragua & Niger & Nigeria & $\begin{array}{l}\text { Norway } \\
\text { Russian }\end{array}$ & Pakistan & Panama & $\begin{array}{l}\text { Paraguay } \\
\text { Slovak }\end{array}$ & Peru & Philippines \\
\hline Poland & Portugal & Romania & Federation & Senegal & $\begin{array}{l}\text { Serbia } \\
\text { Syrian Arab }\end{array}$ & Republic & Slovenia & $\begin{array}{l}\text { South Africa } \\
\text { Trinidad and }\end{array}$ \\
\hline Spain & Sri Lanka & Suriname & Sweden & $\begin{array}{l}\text { Switzerland } \\
\text { United }\end{array}$ & Republic & Thailand & $\begin{array}{l}\text { Togo } \\
\text { Venezuela }\end{array}$ & Tobago \\
\hline $\begin{array}{l}\text { Tunisia } \\
\text { Zimbabwe }\end{array}$ & Turkey & Uganda & Ukraine & Kingdom & United States & Uruguay & $\mathrm{RB}$ & Yemen Rep. \\
\hline
\end{tabular}


Table A4. Countries with a youth bulge higher than the critical level of $19 \%$ in 2012

\begin{tabular}{|c|c|c|c|c|c|}
\hline Country & Corruption $>0$ & Youth $>19 \%$ & Country & Corruption $>0$ & Youth $>19 \%$ \\
\hline Afghanistan & 1.41 & 38.22 & Madagascar & 0.61 & 35.40 \\
\hline Albania & 0.72 & 23.32 & Malawi & 0.45 & 37.72 \\
\hline Algeria & 0.54 & 26.38 & Maldives & 0.44 & 31.14 \\
\hline Angola & 1.29 & 36.99 & Mali & 0.76 & 36.15 \\
\hline Argentina & 0.49 & 21.79 & Mauritania & 0.60 & 32.64 \\
\hline Armenia & 0.53 & 21.49 & Mexico & 0.41 & 25.91 \\
\hline Azerbaijan & 1.07 & 25.05 & $\begin{array}{l}\text { Micronesia, } \\
\text { Fed. Sts. }\end{array}$ & 0.11 & 37.00 \\
\hline Bangladesh & 0.87 & 28.92 & Moldova & 0.60 & 19.65 \\
\hline Benin & 0.92 & 34.79 & Mongolia & 0.52 & 27.43 \\
\hline Bolivia & 0.70 & 31.22 & Morocco & 0.41 & 26.41 \\
\hline Burkina Faso & 0.52 & 36.87 & Mozambique & 0.59 & 35.49 \\
\hline Burundi & 1.46 & 37.10 & Myanmar & 1.12 & 24.07 \\
\hline Cambodia & 1.04 & 29.16 & Nepal & 0.83 & 31.08 \\
\hline Cameroon & 1.24 & 36.06 & Nicaragua & 0.78 & 31.79 \\
\hline $\begin{array}{l}\text { Central African } \\
\text { Republic }\end{array}$ & 0.89 & 34.25 & Niger & 0.69 & 35.08 \\
\hline Chad & 1.25 & 38.78 & Nigeria & 1.13 & 34.03 \\
\hline China & 0.48 & 19.87 & Pakistan & 1.06 & 32.60 \\
\hline Colombia & 0.43 & 25.06 & Panama & 0.39 & 24.04 \\
\hline Comoros & 0.73 & 31.56 & $\begin{array}{l}\text { Papua } \\
\text { Guinea }\end{array}$ & 1.04 & 31.28 \\
\hline $\begin{array}{l}\text { Congo, Dem. } \\
\text { Rep. }\end{array}$ & 1.30 & 36.22 & Paraguay & 0.84 & 29.66 \\
\hline Congo, Rep. & 1.19 & 32.50 & Peru & 0.39 & 26.67 \\
\hline Cote d'Ivoire & 0.91 & 33.90 & Philippines & 0.58 & 30.14 \\
\hline Djibouti & 0.38 & 32.60 & $\begin{array}{l}\text { Sao Tome and } \\
\text { Principe }\end{array}$ & 0.39 & 33.42 \\
\hline $\begin{array}{l}\text { Dominican } \\
\text { Republic }\end{array}$ & 0.83 & 26.80 & Saudi Arabia & 0.06 & 23.39 \\
\hline Ecuador & 0.66 & 26.31 & Senegal & 0.32 & 35.83 \\
\hline Egypt, Arab Rep. & 0.57 & 27.48 & Sierra Leone & 0.94 & 33.57 \\
\hline El Salvador & 0.38 & 31.58 & $\begin{array}{l}\text { Solomon } \\
\text { Islands }\end{array}$ & 0.44 & 32.20 \\
\hline Equatorial Guinea & 1.56 & 31.86 & Somalia & 1.59 & 36.71 \\
\hline Eritrea & 0.65 & 35.31 & South Sudan & 1.34 & 35.27 \\
\hline Ethiopia & 0.60 & 36.64 & Sri Lanka & 0.24 & 20.26 \\
\hline Fiji & 0.44 & 25.29 & Sudan & 1.51 & 33.71 \\
\hline Gabon & 0.55 & 31.84 & Suriname & 0.37 & 23.29 \\
\hline Gambia, The & 0.64 & 36.25 & Swaziland & 0.33 & 39.27 \\
\hline Guatemala & 0.61 & 34.42 & $\begin{array}{l}\text { Syrian Arab } \\
\text { Republic }\end{array}$ & 1.17 & 31.10 \\
\hline Guinea & 1.11 & 34.58 & Tajikistan & 1.18 & 33.56 \\
\hline Guinea-Bissau & 1.22 & 33.92 & Tanzania & 0.85 & 35.35 \\
\hline Guyana & 0.75 & 28.22 & Timor-Leste & 0.98 & 42.10 \\
\hline
\end{tabular}




\begin{tabular}{|c|c|c|c|c|c|}
\hline Country & Corruption $>0$ & Youth $>19 \%$ & Country & Corruption $>0$ & $\begin{array}{l}\text { (continued) } \\
\text { Youth }>\mathbf{1 9 \%}\end{array}$ \\
\hline Haiti & 1.24 & 31.85 & Togo & 0.99 & 34.63 \\
\hline Honduras & 0.94 & 32.96 & Tonga & 0.07 & 30.18 \\
\hline India & 0.57 & 26.54 & $\begin{array}{l}\text { Trinidad and } \\
\text { Tobago }\end{array}$ & 0.29 & 18.84 \\
\hline Indonesia & 0.66 & 23.59 & Tunisia & 0.18 & 22.97 \\
\hline Iran, Islamic Rep. & 0.82 & 25.31 & Turkmenistan & 1.34 & 29.33 \\
\hline Iraq & 1.23 & 33.41 & Uganda & 0.95 & 39.21 \\
\hline Jamaica & 0.36 & 25.80 & Uzbekistan & 1.23 & 30.27 \\
\hline Kazakhstan & 0.88 & 22.91 & $\begin{array}{l}\text { Venezuela, } \\
\text { RB }\end{array}$ & 1.24 & 25.57 \\
\hline Kenya & 1.10 & 34.59 & Vietnam & 0.56 & 24.69 \\
\hline Korea, Dem. Rep. & 1.37 & 20.45 & $\begin{array}{l}\text { West Bank } \\
\text { and Gaza }\end{array}$ & 0.78 & 37.15 \\
\hline Kyrgyz Republic & 1.09 & 30.85 & Yemen, Rep. & 1.23 & 39.00 \\
\hline Lao PDR & 1.04 & 35.81 & Zambia & 0.36 & 36.94 \\
\hline Lebanon & 0.87 & 25.41 & Zimbabwe & 1.27 & 38.84 \\
\hline Liberia & 0.57 & 33.35 & & & \\
\hline Libya & 1.40 & 25.78 & & & \\
\hline
\end{tabular}

Note: Youth is the share of the youth population (15-24 years of age) in the adult population (15 years of age and higher). Corruption is the reversed control of the corruption index of the World Governance Indicators. 
Table A5. Comparing OLS and robust estimators.

Dependent variable: ICRG Political Stability (stab_icrg)

\begin{tabular}{|c|c|c|}
\hline & OLS (Model 4.6 in Table 4) & robust estimator \\
\hline \multirow[t]{2}{*}{ L. wgi_corruption (reversed) } & $1.248^{* * *}$ & $0.736^{*}$ \\
\hline & $(2.82)$ & $(2.47)$ \\
\hline \multirow[t]{2}{*}{ L. youth2029_20plus } & -0.0561 & -0.0578 \\
\hline & $(-0.95)$ & $(-1.46)$ \\
\hline \multirow[t]{2}{*}{ L. wgi_corruption*youth2029_20plus } & $-0.0550 * * *$ & $-0.0457 * * *$ \\
\hline & $(-3.57)$ & $(-4.42)$ \\
\hline \multirow[t]{2}{*}{ L. van_youth2029_20plus } & 0.00124 & 0.000903 \\
\hline & $(1.34)$ & $(1.45)$ \\
\hline \multirow[t]{2}{*}{ L. gdppcg_youth2029_20plus } & -0.00119 & -0.000773 \\
\hline & $(-1.46)$ & $(-1.41)$ \\
\hline \multirow[t]{2}{*}{ L. unempyouth_youth2029_20plus } & -0.00106 & -0.000399 \\
\hline & $(-1.21)$ & $(-0.68)$ \\
\hline \multirow[t]{2}{*}{ L. secondary_youth2029_20plus } & 0.000805 & 0.000554 \\
\hline & $(1.65)$ & $(1.69)$ \\
\hline \multirow[t]{2}{*}{ L. youth_unemployment } & -0.00566 & -0.00586 \\
\hline & $(-0.27)$ & $(-0.42)$ \\
\hline \multirow[t]{2}{*}{ L. population growth } & 0.0577 & 0.00423 \\
\hline & $(0.63)$ & $(0.07)$ \\
\hline \multirow[t]{2}{*}{ L.GDP per capita growth ( $g d p p c g$ ) } & 0.0420 & $0.0376^{*}$ \\
\hline & $(1.84)$ & $(2.46)$ \\
\hline \multirow[t]{2}{*}{ L. fdi_gdp } & 0.00189 & 0.00117 \\
\hline & $(0.53)$ & $(0.48)$ \\
\hline \multirow[t]{2}{*}{ L. trade_gdp } & -0.00222 & -0.000954 \\
\hline & $(-0.81)$ & $(-0.52)$ \\
\hline \multirow[t]{2}{*}{ L. secondary_enrolment } & $-0.0232 *$ & $-0.0159 *$ \\
\hline & $(-1.98)$ & $(-2.02)$ \\
\hline \multirow[t]{2}{*}{ L. totalrent_gdp } & 0.00625 & 0.00467 \\
\hline & $(0.87)$ & $(0.97)$ \\
\hline \multirow[t]{2}{*}{ L. van_index } & -0.0243 & -0.0238 \\
\hline & $(-1.00)$ & $(-1.45)$ \\
\hline \multirow[t]{2}{*}{ L. gini_net } & 0.00445 & $-0.0241 *$ \\
\hline & $(0.30)$ & $(-2.42)$ \\
\hline Country dummies & Yes & Yes \\
\hline Time dummies & Yes & Yes \\
\hline $\mathrm{N}$ & 819 & 818 \\
\hline R-sq & 0.90 & 0.95 \\
\hline
\end{tabular}

Note: $t$ statistics are in parentheses. We use ordinary standard errors because leverage plot is not available for robust standard errors in Stata. Constant term is included but not reported. Robust regression is an alternative to the OLS method, dealing with possible effects of outliers and influential observations. Stata's rreg command is used to estimate robust regression. *Significantly different from zero at $90 \%, * * 95 \%$, and $* * * 99 \%$ confidence. 